Copyright by the American Society of Agricultural and Biological Engineers. Benham, B. L.; Baffaut, C.; Zeckoski, R. W.; Mankin, K. R.; Pachepsky, Y. A.; Sadeghi, A. A.; Brannan, K. M.; Soupir, M. L.; Habersack, M. J., "Modeling bacteria fate and transport in watersheds to support TMDLs," Transactions of the ASABE. Vol. 49(4): 987-1002. (doi: 10.13031/2013.21739) @2006

\title{
Modeling Bacteria FATE AND TRANSPORT IN WATERSHEDS TO SUPPORT TMDLS
}

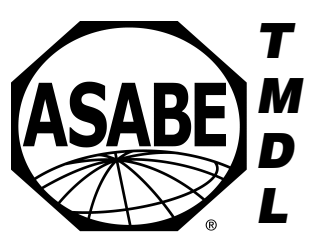

\author{
B. L. Benham，C. Baffaut，R. W. Zeckoski，K. R. Mankin，Y. A. Pachepsky,
} A. M. Sadeghi, K. M. Brannan, M. L. Soupir, M. J. Habersack

\begin{abstract}
Fecal contamination of surface waters is a critical water-quality issue, leading to human illnesses and deaths. Total Maximum Daily Loads (TMDLs), which set pollutant limits, are being developed to address fecal bacteria impairments. Watershed models are widely used to support TMDLs, although their use for simulating in-stream fecal bacteria concentrations is somewhat rudimentary. This article provides an overview of fecal microorganism fate and transport within watersheds, describes current watershed models used to simulate microbial transport, and presents case studies demonstrating model use. Bacterial modeling capabilities and limitations for setting TMDL limits are described for two widely used watershed models (HSPF and SWAT) and for the load-duration method. Both HSPF and SWAT permit the user to discretize a watershed spatially and bacteria loads temporally. However, the options and flexibilities are limited. The models are also limited in their ability to describe bacterial life cycles and in their ability to adequately simulate bacteria concentrations during extreme climatic conditions. The load-duration method for developing TMDLs provides a good representation of overall water quality and needed water quality improvement, but intra-watershed contributions must be determined through supplemental sampling or through subsequent modeling that relates land use and hydrologic response to bacterial concentrations. Identified research needs include improved bacteria source characterization procedures, data to support such procedures, and modeling advances including better representation of bacteria life cycles, inclusion of more appropriate fate and transport processes, improved simulation of catastrophic conditions, and creation of a decision support tool to aid users in selecting an appropriate model or method for TMDL development.
\end{abstract}

Keywords. Fecal bacteria, HSPF, Modeling, Pathogens, SWAT, TMDL, Water quality, Watershed.

$\mathrm{F}$ ecal pathogen contamination of surface waters can result in illness and death, and it accounts for a majority of the assessed water-quality impairments in the U.S. (USEPA, 2005a). Fecal coliform bacteria are often used as indicators of the potential presence of fecal pathogens. Waterborne disease outbreaks are defined by the Centers for Disease Control and Prevention (CDC) as incidences in which more than two persons have experienced an illness after ingesting drinking water or after recreational

Submitted for review in February 2006 as manuscript number SW 6351; approved for publication by the Soil \& Water Division of ASABE in July 2006.

The authors are Brian L. Benham, ASABE Member Engineer, Extension Specialist and Assistant Professor, Rebecca W. Zeckoski, ASABE Member Engineer, Research Associate, Kevin M. Brannan, ASABE Member Engineer, Research Associate, Michelle L. Soupir ASABE Student Member, Graduate Research Assistant, and Matthew J. Habersack, ASABE Student Member, Graduate Research Assistant, Department of Biological Systems Engineering, Virginia Tech, Blacksburg, Virginia; Claire Baffaut, Program Director, Food and Agricultural Policy Research Institute, University of Missouri, Columbia, Missouri; Kyle R. Mankin, ASABE Member Engineer, Associate Professor, Department of Biological and Agricultural Engineering, Kansas State University, Manhattan, Kansas; Yakov A. Pachepsky, Soil Scientist, USDA-ARS Environmental Microbial Safety Laboratory, Beltsville, Maryland; and Ali M. Shadeghi, ASABE Member Engineer, Soil Physicist, USDA-ARS Hydrology and Remote Sensing Laboratory, Beltsville, Maryland. Corresponding author: Brian L. Benham, Department of Biological Systems Engineering, 209 Seitz Hall, Virginia Tech, Blacksburg, VA 24061; phone: 540-231-5705; fax: 540-231-3199; e-mail: benham@vt.edu. contact with water where epidemiologic evidence implicates water as the probable source of the illness. Between 1971 and 2000 , there were 1,010 reported waterborne disease outbreaks, corresponding to 594,340 cases of illness (Wang, 2003). A majority of outbreaks $(513 ; 51 \%)$ and cases of illness $(505,189 ; 85 \%)$ were caused by pathogenic bacteria, viruses, or protozoa. Fecal bacteria excreted by humans, domestic animals, and wildlife can enter natural water sources with stormwater runoff, from inadequate sanitary facilities, and through direct deposition. Curriero et al. (2001) found that more than half the waterborne disease outbreaks in the U.S. in the past 50 years were preceded by heavy rainfall.

An excessive quantity of fecal bacteria in surface water increases the risk of bacteria-induced illness to humans (Frenzel and Couvillion, 2002). Payment et al. (2000) found that the occurrence of pathogenic microorganisms (human enteric virus, Cryptosporidium, and Giardia) in the Saint Lawrence River in Canada was significantly correlated with bacterial indicators (total coliform, fecal coliform, and Clostridium perfringens). A fecal coliform concentration of 200 colony-forming units (cfu) per $100 \mathrm{~mL}$ of water was established as a water-quality standard by the Federal Water Pollution Control Administration of the Department of the Interior in 1968 (USEPA, 1986). More recent research, however, demonstrated that fecal coliforms had less correlation to swimming-associated gastroenteritis than the other two common indicator bacteria (Escherichia coli and enterococci), prompting a shift in the recommended indicator organisms (USEPA, 1998, 2002). 
Nationwide, a total of 7,800 stream segments have been reported with bacteria impairments, each requiring development and implementation of a pollutant-specific Total Maximum Daily Load (TMDL) to meet the water-quality standard for bacteria in their respective states (USEPA, 2005a). The TMDL program, which is mandated by the Clean Water Act (33 U.S.C. $§ \S 1251-1387$ ), is a watershed management process that integrates watershed planning and remediation with water quality assessment and protection. For the USEPA to approve a TMDL, all major point and nonpoint sources of the offending pollutant(s) must be identified and quantified. Developing a TMDL involves a study that quantifies the pollutant contribution from each source (or source category in the case of nonpoint-source pollution) and determines the pollutant reduction from each source required to meet applicable state water-quality standards. Hydrologic and water-quality models are often used to determine the pollutant reduction from each source needed to meet applicable state water-quality standards.

This article is one of a special collection of TMDL modeling-related article published by ASABE (Muñoz-Carpena et al., 2006). The objectives of this article are:

- To present an overview of the sources, fate, and transport of bacteria in the environment.

- To describe the models currently used to develop bacteria-impairment TMDLs and discuss their strengths and weaknesses.

- To present case studies demonstrating the use of the models.

- To describe research needed to advance the science for developing bacteria-impairment TMDLs.

\section{BaCteria Water-Quality StandardS BRIEF BACKGROUND}

Water-quality standards include water-quality criteria designed to protect the quality of water bodies for specific designated uses. A water-quality criterion is a numeric or narrative measure of a pollutant that is deemed acceptable for the designated use of the water body (USEPA, 2005b). For bacteria, the criterion typically is the concentration of one or more bacteria species that are indicative of the presence of pathogens. The designated uses that relate to bacteria and pathogens include drinking water, recreation, and fishing.

Because drinking water is treated before being distributed, and because treatment to eliminate bacteria (fecal coliform, $E$. coli, and enterococci) has been shown to be effective in controlling pathogens, there are currently no surface waters listed as impaired for violating drinking water criteria. Waters designated for "primary contact" recreational use are subject to the most stringent indicator bacteria standards, and thus are the most likely to be listed as impaired. Since the majority of recreational activity occurs only during fair weather, many states include a temporal component in their bacteria standards.

\section{INDICATOR ORGANISMS}

A water-quality indicator organism is one whose presence, absence, or population density is related to the risks of illness to the users of the water. Epidemiological studies have been conducted to determine which organisms are good indicators of illness risk and to establish what concentration levels are safe.
Total coliform, fecal coliform, fecal streptococci, enterococci, and $E$. coli bacteria are common indicator species used to identify the potential presence of pathogens. Ideally, indicators for pathogens exist in much greater concentrations, exhibit similar die-off and re-growth patterns, and are associated with the same sources (Moore et al., 1982). The first indicator used to test for contamination of drinking water by human waste was total coliform. Since specific pathogens are very difficult to collect and culture, the total coliform group was initially chosen as an indicator because it was easy to detect, simple to culture, and typically is associated with fecal contamination from warm-blooded animals (Larsen et al., 1994). However, total coliforms include numerous organisms present in non-fecal sources, making this indicator group too broad to be a reliable indicator of fecal pathogens (Rosen, 2000).

Fecal coliforms are a subgroup of total coliforms that originate specifically from the intestinal tracts of warmblooded animals. Fecal coliforms are the predominant indicator used to assess human health hazards in streams (Rosen, 2000), but E. coli and enterococci are thought to have a higher degree of association with outbreaks of gastrointestinal illness (USEPA, 1986). E. coli is a member of the fecal coliform group and includes the toxin-producing O157:H7 strain. Enterococci is a subgroup of fecal streptococci that belongs to the genus Streptococcus and differs from fecal coliforms in that enterococci are less numerous in feces, are not known to reproduce in the environment, and are more resistant to environmental stress (Maier et al., 2000).

\section{Bacteria Fate and Transport}

A process-based approach to modeling fecal bacteria fate and transport in a watershed considers release from manure, overland transport with water and sediment, in-stream transport, infiltration into soil, transport in the vadose zone and groundwater, and die-off and growth throughout the storage and transport processes. Simulated fecal bacteria fate and transport are dependent on simulated water and sediment transport processes. As such, current models have adapted existing hydrologic and erosion models as vehicles for bacteria fate and transport calculations. The two models commonly used for watershed-scale bacterial fate and transport in the U.S. are Hydrological Simulation ProgramFORTRAN (HSPF; Bicknell et al., 1997) and the Soil and Water Assessment Tool (SWAT; Sadeghi and Arnold, 2002).

\section{RELEASE FROM MANURE}

SWAT uses a linear relationship to simulate release of manure-borne microorganisms:

$$
\Delta M_{R}=M_{s} k_{1} \Delta Q
$$

while HSPF employs an exponential relationship given by equation 2:

$$
\Delta M_{R}=M_{S}\left[1-\exp \left(-k_{2} \Delta Q\right)\right]
$$

where $\Delta M_{R}$ is the amount of bacteria released during time interval $\Delta t$ during the runoff event (cfu), $M_{S}$ is the amount of bacteria in the manure storage layer of the soil at the beginning of time interval $\Delta t$ (cfu), $\Delta Q$ is runoff yield per $\Delta t$ interval $(\mathrm{cm})$, and $k_{1}$ and $k_{2}$ are release-rate constants $\left(\mathrm{cm}^{-1}\right)$. 
Release parameters are often related to land use (VDEQ, 2003). Other factors influencing bacteria release from manure include manure age (Springer et al., 1983; Thelin and Gifford, 1983), application methods (Soupir et al., 2006; Drapcho and Hubbs, 2003), model scale (Guber et al., 2005; Shelton et al., 2003), and storm duration and timing (Guber et al., 2005).

Vadas et al. (2004) suggested using the power-law relationship for the amount of phosphorus released from manure. When applied to bacteria, this equation becomes:

$$
M_{R}=M_{m} a\left(\frac{\rho_{w} Q}{M_{d}}\right)^{b}
$$

where $M_{m}$ is the amount of bacteria in surface-applied manure before the runoff event (cfu), $Q$ is runoff depth $(\mathrm{cm}), M_{d}$ is dry mass of applied manure $\left(\mathrm{g} \mathrm{cm}^{-2}\right), \rho_{\omega}$ is density of water $\left(\mathrm{g} \mathrm{cm}^{-3}\right)$, and $a$ and $b$ are dimensionless fitting parameters. Guber et al. (2005) applied the model of Bradford and Schijven (2002) and obtained:

$$
M_{R}=M_{m}\left[1-\left(1+k_{3} \beta Q\right)^{\beta}\right]
$$

where $k_{3}$ and $\beta$ are dimensionless fitting parameters.

\section{PARTitioning ANd Adsorption}

Fecal bacteria are partitioned into soluble and sorbed phases during their initial release from manure, overland and subsurface transport, and stream and bed transport (Sadeghi and Arnold, 2002; Bicknell et al., 1997). The models SWAT and HSPF assume a linear partitioning relationship:

$$
S=K_{d} C
$$

where $S$ is the adsorbed bacteria density (cfu $\mathrm{g}^{-1}$ ), $C$ is the bacteria concentration in solution $(\mathrm{cfu} \mathrm{mL}-1)$, and $K_{d}$ is the linear partitioning coefficient $\left(\mathrm{mL} \mathrm{g}^{-1}\right)$. Several kinetic adsorption-desorption equations have been used to simulate bacteria transport at the soil-pore scale (Bengtsson and Lindquist, 1995; Murphy and Ginn, 2000) but have not found application at the watershed scale.

Relatively little is known about the factors influencing adsorption parameter values. The literature contains values of the $E$. coli $K_{d}$ varying from $2 \times 10^{-1}$ to $2 \times 10^{3} \mathrm{~mL} \mathrm{~g}^{-1}$. Clay content is thought to be the leading factor affecting $K_{d}$ (Hagedorn et al., 1978), although relationships between $K_{d}$ and clay content have large uncertainty (Bengtsson, 1989). Other factors influencing bacterial attachment to soil include soil hydrophobicity (Lindqvist and Bengtsson, 1991), presence of other bacteria (Marshall et al., 1971), ions (Gilbert et al., 1976; Tay et al., 1994; Gannon et al., 1991; Jackson et al., 1994), and electrostatic interactions (Sharma et al., 1985). Recently, Guber et al. (2005) showed that the presence of manure particulates drastically changes $E$. coli adsorption to soils.

\section{SURVIVAL}

Chick's law (eq. 6) is used in both SWAT and HSPF to describe the survival of $E$. coli and fecal coliform in stored manure, soil, land-applied manure, streams, and groundwater over time:

$$
N=N_{0} \exp (-\mu t)
$$

where $N$ is the number of indicator bacteria at time $t$ (cfu), $N_{0}$ is the original number of indicator bacteria (cfu), $\mu$ is the die-off rate constant $\left(\mathrm{h}^{-1}\right)$, and $t$ is time $(\mathrm{h})$. The die-off rates of fecal coliforms and $E$. coli in soil are affected by many factors. An increase in moisture content causes a decrease in die-off rate constants (Reddy et al., 1981; Mubiru et al., 2000). High soil pH increases die-off (Gerba et al., 1975; Ellis and McCalla, 1976), with $\mathrm{pH}$ of 6 to 7 being the most favorable for bacterial survival (Cuthbert et al., 1955; Reddy et al., 1981). Unc and Goss (2006) found that type of manure affects survival. In HSPF and SWAT, however, temperature is the only environmental variable that is used to modify die-off:

$$
\mu=\mu_{20} \theta^{T-20}
$$

where $\mu_{20}$ is the die-off rate at $20^{\circ} \mathrm{C}\left(\mathrm{h}^{-1}\right), \theta$ is the unitless temperature correction parameter for the first-order decay, and $T$ is the temperature $\left({ }^{\circ} \mathrm{C}\right)$. While the value of $\theta$ is relatively constant with a value around 1.07 in all four environments of interest, namely, stored manure, soil, land-applied manure, and streams, the value of $\mu_{20}$ varies considerably (Crane and Moore, 1986). A review by Crane and Moore (1986) found $\mu$ values ranging from 0.1 to $2 \mathrm{~d}^{-1}$ in soils. Temperature varied among the experiments reviewed in this work. The wide range of values is an indication that there may be limited applicability in using a single die-off parameter $(\mu)$ modified only by temperature to describe actual data on survival. Experimental data on manure-borne $E$. coli indicate that die-off rarely follows Chick's law. Most field experiments show that, like bacterial growth, die-off also occurs in phases. These phases differ with the physical location of the bacteria, suspended (planktonic), attached, or resuspended after being attached to soil. Additional research is needed to identify and define bacteria die-off phases and develop models to describe die-off under a variety of conditions.

\section{TransPorT}

The mass flux of water-borne indicator bacteria along overland transport pathways is currently simulated assuming that bacteria are dissolved constituents. The algorithm used for bacteria mass flux in SWAT and HSPF is purely advective:

$$
q=v C
$$

where $q$ is bacterial flux per unit cross-sectional area (cfu $\left.\mathrm{cm}^{-2} \mathrm{~h}^{-1}\right), v$ is flow velocity $\left(\mathrm{cm} \mathrm{h}^{-1}\right)$, and $C$ is bacteria concentration $\left(\mathrm{cfu} \mathrm{cm}^{-3}\right)$. The possible effect of dispersion is typically taken into account in overland modeling at the hillslope scale and in groundwater modeling.

Experiments on bacteria transport in soils and groundwater usually conclude that bacteria move in the subsurface and that temporal or permanent water saturation allows indicator bacteria to move quite far along preferential pathways (Jamieson et al., 2002, Ferguson et al., 2003, Tyrrel and Quinton, 2003). On the surface, transport in rills may move larger amounts of bacteria when compared to overland sheet flow. At the same time, surface microponds provide an accumulating capacity that has a limited exchange with the fast-moving water in rills. Manure-borne organisms are released with manure particulates that may serve as carriers and provide nutrients for indicator organisms. Observations of concurrent transport of manure particulate matter and indicator bacteria show that manure particulates seem to facilitate bacteria transport (Shelton et al., 2002; Guber et al., 2005). 
Table 1. Common bacteria sources considered in TMDL studies.

\begin{tabular}{|c|c|c|c|}
\hline $\begin{array}{l}\text { Source } \\
\text { Category }\end{array}$ & $\begin{array}{l}\text { Location or Pathway } \\
\text { Considered }\end{array}$ & Typical Sources & Bacteria Production Information ${ }^{[a]}$ \\
\hline \multirow{5}{*}{ Livestock } & \multirow{5}{*}{$\begin{array}{l}\text { Deposition on land, } \\
\text { deposition in streams, } \\
\text { manure storage and } \\
\text { application }\end{array}$} & Cattle (dairy and beef) & $\begin{array}{l}\text { ASAE Standards, 1998; Yagow, 2001; Geldreich, 1978; } \\
\text { USEPA, 2003; NCSU, } 1994\end{array}$ \\
\hline & & Horses & ASAE Standards, 1998; USEPA, 2003; Geldreich, 1978 \\
\hline & & Swine & ASAE Standards, 1998; Geldreich, 1978 \\
\hline & & Sheep and goats & ASAE Standards, 1998; USEPA, 2003; Geldreich, 1978 \\
\hline & & Poultry & $\begin{array}{l}\text { ASAE Standards, 1998; Geldreich, 1978; } \\
\text { Hartel et al., 2000; Pope and Cherry, } 2000\end{array}$ \\
\hline \multirow{5}{*}{ Wildlife $^{[b]}$} & \multirow{5}{*}{$\begin{array}{l}\text { Deposition on land, } \\
\text { deposition in streams, } \\
\text { residential storm runoff }\end{array}$} & Deer & Yagow, 2001; USEPA, 2004 (pp. 4-12) \\
\hline & & Ducks & ASAE Standards, 1998; Geldreich, 1978 \\
\hline & & Geese & Alderisio and DeLuca, 1999; Moyer and Hyer, 2003 \\
\hline & & Beaver & MapTech, 2000 \\
\hline & & Muskrats & Yagow, 2001 \\
\hline \multirow{3}{*}{ Residential } & \multirow{3}{*}{$\begin{array}{l}\text { Failing or inadequate septic } \\
\text { systems, straight pipes, } \\
\text { stormwater runoff, } \\
\text { leaking sewer systems, } \\
\text { illicit sewer connections }\end{array}$} & Humans & Geldreich, 1978; MDEQ, 2002 \\
\hline & & Pets & Geldreich, 1978; Horsley Whitten, 1996 \\
\hline & & Stormwater runoff & $\begin{array}{l}\text { Koppelman and Tanenbaum, 1982; } \\
\text { Young and Thackston, } 1999\end{array}$ \\
\hline \multirow[t]{2}{*}{ Permitted } & $\begin{array}{l}\text { Permitted discharges, } \\
\text { recorded sewer overflows }\end{array}$ & $\begin{array}{l}\text { National Pollutant Discharge } \\
\text { Elimination System (NPDES) }\end{array}$ & Discharge monitoring reports \\
\hline & Land application & Municipal biosolids & Application records \\
\hline
\end{tabular}

[a] Cited references have information on either the daily production of bacteria from each source or the concentration of bacteria in feces for each source.

[b] Actual counts of wildlife populations are often not obtained for TMDL studies. Rather, an estimate is used of bacteria concentrations observed flowing from a "pristine" location, or bacteria production is extrapolated based on the bacteria production of a dominant source, such as deer, and the relative weights and population sizes of other expected wildlife populations.

\section{Current Technology And Modeling ToOLS \\ BACTERIA IMPAIRMENT TMDLS: SOURCE Characterization}

Sources considered in TMDL development vary considerably according to the characteristics of the watershed for which the TMDL is being developed. A survey of 19 bacteria TMDL reports from across the U.S. showed four general sources considered in almost every case: failing or inadequate septic systems or other home-based wastewater treatment systems, wildlife, livestock, and improperly managed permitted facilities (table 1). Sources found more commonly in urban areas were pets, urban stormwater runoff, combined or sanitary sewer overflows, leaky sewer lines, and illicit sewer connections. A TMDL from Washington State considered seals as a potential bacteria source (Joy, 2004).
Four of the TMDLs considered contributions from humans directly defecating on the ground or in the stream, by either homeless individuals or recreational users.

\section{Quantifying Source Contributions}

TMDL developers draw upon numerous information sources to characterize bacteria sources and develop model inputs. The types of information gathered generally include hydrography, land use and cover, human demographics, agriculture production, and wildlife habitats (table 2). The information is often available in a GIS format but may also come from experts, government personnel, or local residents. The U.S. Environmental Protection Agency (USEPA) has assembled data sets based on 8-digit hydrologic unit areas nationwide in its Better Assessment Science Integrating Point and Nonpoint Sources (BASINS) modeling system (USEPA, 2001), but more detailed local data are often needed. Many

Table 2. Common information sources used to quantify bacteria sources.

\begin{tabular}{|c|c|c|}
\hline Information Category & Uses & Information Sources \\
\hline Land use and cover & $\begin{array}{l}\text { Animal numbers (agricultural and wildlife); } \\
\text { General source characterization (urban, rural, } \\
\text { agricultural, etc.) }\end{array}$ & $\begin{array}{l}\text { National Land Cover Dataset (NLCD); USGS Digital Raster Graphic } \\
\text { (DRG) or Digital Ortho Quarter Quads (DOQQ); state agencies or } \\
\text { organizations }\end{array}$ \\
\hline $\begin{array}{l}\text { Political boundaries, } \\
\text { roads, sewered areas }\end{array}$ & Human demographics, presentations & $\begin{array}{l}\text { U.S. Census Topologically Integrated Geographic Encoding and } \\
\text { Referencing (TIGER) data; state agencies or localities }\end{array}$ \\
\hline $\begin{array}{l}\text { Permitted facilities } \\
\text { and activities }\end{array}$ & Waste load allocation, human sources & State environmental agencies; NPDES permits and others \\
\hline Livestock & $\begin{array}{l}\text { Livestock types, numbers, waste handling, } \\
\text { agronomic practices }\end{array}$ & $\begin{array}{l}\text { National Agricultural Statistics Service (NASS); Cooperative Exten- } \\
\text { sion and Natural Resource Conservation Service (NRCS) personnel; } \\
\text { state agricultural agencies; local citizens }\end{array}$ \\
\hline Humans & Potential sources, magnitude of sources & U.S. Census data; county sanitarians \\
\hline Wildlife & Species present, population numbers & $\begin{array}{l}\text { State and federal wildlife agencies; National Trappers Association } \\
\text { members; local citizens }\end{array}$ \\
\hline
\end{tabular}


different types of spatial data are available at the U.S. Geological Survey (USGS) Earth Resources Observation and Science (EROS) Data Center (USGS, 2005). Spatial data are used to estimate values needed for source characterization, such as livestock or wildlife populations and their distributions within the watershed.

Federal, state, and local government personnel are critical sources of information for items ranging from wildlife habitat and population densities to permitted facilities (discharges and animal production) (Benham et al., 2005) and the extent of sewered areas (Parajuli et al., 2005). Local input from watershed stakeholders is often the most important source of information and can provide critical feedback to refine estimates. Information from local residents can be obtained through stakeholder meetings, mail surveys, phone conversations, or other personal contact.

\section{Tools to Quantify Source Contributions}

Two spreadsheet-based tools, the Bacteria Indicator Tool (BIT) and the Bacteria Source Load Calculator (BSLC), are available to aid in the compilation of bacteria information. Both tools organize the various bacteria source inputs distributed throughout a watershed, require user input of animal populations, calculate the production of bacteria within the watershed based on literature values for bacteria production and management practices, and generate bacteria loads for use in a watershed model. The BIT (USEPA, 2000) is used as a companion to BASINS and allows inputs of many animal types, including a generic livestock and a generic wildlife type to represent animals not accounted for in the spreadsheet, for up to ten subwatersheds. Quantities of bacteria loading are generated from the tool and can be transferred to HSPF input files after additional processing. The BSLC (Zeckoski et al., 2005) also allows inputs of many animal types and land use information for up to 20 subwatersheds. The bacteria loadings calculated by either tool could be reformatted to provide inputs necessary for different watershed models.

\section{Comparison of Models and Methods Used to DEVELOP BACTERIA-IMPAIRMENT TMDLS}

Comparisons of the approach, assumptions, and capabilities of existing water-quality assessment models have been recently published (Borah and Bera, 2003; Neilson et al., 2003). It was found that every model has its strengths and weaknesses, and the choice of model should depend on several factors, including: (1) scientific and modeling background of the model user; (2) time and cost associated with data pre-processing, running the model, and data post-processing; and (3) informational needs of watershed stakeholders. However, the primary criterion typically considered in model selection is in-house expertise, which dramatically lowers modeling costs. What follows is a summary comparison of the models and methods used to develop bacteria-impairment TMDLs.

\section{Bacteria-Modeling CAPABilities of HSPF}

HSPF is a watershed-scale, process-oriented, lumpedparameter model designed to allow continuous simulation of hydrology and water quality (for both pollutant loading and in-stream processes). HSPF represents spatial variability by dividing the watershed into hydrologically homogenous land segments. HSPF simulates hydrology and water-quality processes occurring on pervious areas, impervious areas, and in reaches or reservoirs.

\section{Source Inputs}

Bacteria nonpoint-source (NPS) loads to the land surface are estimated outside HSPF and then input using parameter values equivalent to a monthly load. This load can be unique for each pervious or impervious land segment. Typically, a pervious land segment represents a unique land use in a unique subwatershed, and impervious land segments are commonly aggregated by land use and are given the same loading for each subwatershed. However, the user may create as many unique pervious or impervious land segments (with unique bacteria loadings) as needed within the computational limitations of HSPF. Direct bacteria loads (e.g., loads deposited directly into the stream by cattle and wildlife and permitted or non-permitted discharges) are input using a time series and are associated with a particular reach or reservoir in the model. Two model parameters define groundwater and interflow bacteria concentrations; these two concentrations can vary monthly but are typically constant throughout the year for each unique pervious land segment.

\section{Die-Off}

Bacteria die-off on the land surface is indirectly represented via a limit on surface accumulation. Given Chick's law (eq. 6) and a constant daily load to the land surface, the total amount of bacteria on the land surface will reach an asymptotic limit. This limit, calculated from a known or estimated die-off rate, defines the limit of surface accumulation. The limit value can be specified on a monthly basis and independently for each land segment in HSPF. In-stream die-off is modeled using a temperature-corrected first-order decay function, Chick's law (eq. 6).

\section{Release and Transport}

A user-defined parameter sets the rate of runoff needed to wash off $90 \%$ of bacteria load on land surface. As typically applied, HSPF provides no provision for partitioning bacteria between attached and suspended phases. Released bacteria are modeled in overland runoff, in the stream, and in groundwater as suspended or planktonic constituents.

\section{BMPs}

Best management practices (BMPs) can be represented in a simple fashion by a percent removal of bacteria in the best management practice evaluation (BMPRAC) module of HSPF. Reduction factors specified in this module are multiplied by the bacteria output from the area impacted by the BMP. For example, a reduction factor could be applied to bacteria losses from a pervious area with a BMP, such as pasture with improved grazing. More complex BMPs or systems of BMPs can be directly simulated, but doing so is complicated and requires specific expertise (Donigian et al., 1991).

\section{Bacteria-Modeling Capabilities of SWAT}

SWAT is a watershed-scale, process-oriented, lumpedparameter model that allows continuous simulation to predict the impact of land use and land management practices on water quantity and quality (Arnold and Fohrer, 2005). Runoff, leaching, and pollutant loadings are estimated separately for each hydrologic response unit (HRU), which represents a unique combination of soil, land use, and 
topography in each subwatershed. Flows and pollutant loads are routed through the watershed's stream network to obtain total water and pollutant yields.

\section{Source Inputs}

Management practices and bacteria inputs are specified for each HRU. Animal manure or organic fertilizer can be applied to the land surface. For each animal manure or organic fertilizer, the initial bacteria concentrations are specified in counts per kilogram of dry matter for two types of bacteria: persistent and less persistent (with shorter half-life). Bacteria in the top $10 \mathrm{~mm}$ of soil are partitioned into bacteria in soil solution and bacteria adsorbed to soil particles.

\section{Die-Off}

Bacteria are assumed to die off according to Chick's law. The overall rate of bacteria loss is equal to the die-off rate less the re-growth rate. Different die-off rates are specified for bacteria present on foliage, in soil solution, and adsorbed to soil particles (Mancini, 1978). Die-off rates are also specified for persistent and less persistent bacteria in streams and reservoirs. Die-off rates are independent of bacteria source and are adjusted for temperature.

\section{Release and Transport}

The release of bacteria in SWAT mimics processes that are used for phosphorous (eq. 3). A user-defined fraction of bacteria that lands on foliage due to manure application washes off when daily precipitation is greater than $2.54 \mathrm{~mm}$ and lands on the soil, where it is combined with the bacteria in soil solution. If runoff occurs, bacteria concentrations in overland flow are calculated based on the runoff volume, bacteria available in soil solution, soil bulk density, and a bacteria runoff partitioning coefficient: the ratio of the soil-solution bacteria concentration in the top $10 \mathrm{~mm}$ of soil to the bacteria concentration in surface runoff. This coefficient is constant for all bacteria regardless of source. Bacteria below the top $10 \mathrm{~mm}$ of soil are assumed to stay in the soil profile. Bacteria adsorbed to soil particles can move when there is soil erosion. The bacteria that move with soil particles are calculated with a loading function (McElroy et al., 1976; Williams and Haan, 1978) that considers the concentration of bacteria adsorbed to sediment in the top $10 \mathrm{~mm}$ of soil, the sediment yield, and a bacteria enrichment ratio calculated using a relationship developed by Menzel (1980).

\section{BMPS}

BMPs are individually specified and simulated. The bacteria-related BMPs that can be simulated by SWAT are composting, intensive grazing, sewage treatment, edge-offield filters, catchment ponds, and manure incorporation.

\section{LOAD-DuRATION METHOD}

The load-duration method has been used in Kansas to display TMDL limits for daily bacterial loads over the range of flows seen at specific stream locations and to determine the hydrologic conditions under which any violations of those limits tend to occur (Stiles, 2001, 2002). The first step in this method is to establish an upper-bound daily bacterial load for a given stream location, typically obtained by multiplying a target TMDL bacterial concentration (e.g., $200 \mathrm{cfu}$ $100 \mathrm{~mL}^{-1}$ ) by historic daily flow rates. The resulting daily maximum bacterial loads are plotted over the range of historic streamflows, expressed as daily streamflow excee- dance percentages. The resulting line represents the TMDL as the upper-bound of daily bacterial loads (cfu day $\left.{ }^{-1}\right)$. The period of record of daily flows used to construct the load duration curve may be chosen to account for long-term flow conditions or to coincide with the period of record for available water-quality data. The second step is to compare measured bacterial loads to the frequency-based limits. In-stream bacterial concentrations are measured and converted to daily bacterial loads using measured, modeled, or estimated daily streamflow values. The daily bacterial load is plotted at the corresponding daily streamflow exceedance percentage associated with the flow occurring on the day of sampling, and then compared to the allowable bacterial loading line. Bacterial loads that are plotted above the upperbound TMDL line are exceedances of the water-quality criterion.

Graphical presentation of the bacterial loads together with the hydrologic flow conditions (expressed as exceedance values) provides a context for interpreting the bacterial data. Bacterial load exceedances that occur at low-flow conditions suggest different sources (e.g., point-source discharges) and remediation methods (e.g., disinfection) than exceedances at moderate- or high-flow conditions, suggestive of wetweather sources (combined sewer overflows or runoff from livestock grazing areas). Because this method uses measured in-stream bacterial concentrations, it inherently accounts for appropriate watershed and in-stream bacterial processes. Use of measured in-stream data makes the estimates specific to the given watershed, stream, season, and hydrologic condition for which the samples were collected.

\section{Case Studies}

\section{hSPF Case Study: Mill Creek Bacteria Impairment TMDL STUDY \\ Watershed Description}

Mill Creek is a small watershed $\left(33.3 \mathrm{~km}^{2}\right)$ located in Page County, Virginia (fig. 1). Mill Creek is located in a rolling valley between two mountain ranges. Land uses in Mill

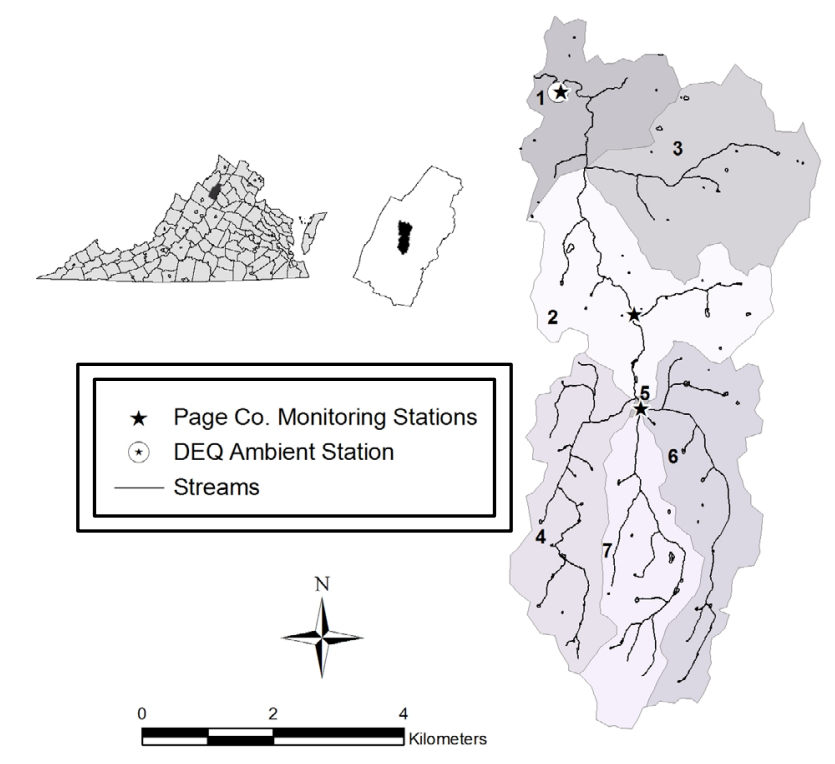

Figure 1. Mill Creek (VAV-B38R) with subwatersheds and water-quality monitoring stations. 
Creek include pasture (70\%), forest (19\%), residential (6\%), and cropland (5\%).

\section{Water-Quality Impairment}

Fifty-one percent of the water-quality samples collected in Mill Creek from December 1991 to June 1997 violated the freshwater single-sample water-quality criterion for fecal coliform: $1,000 \mathrm{cfu}$ per $100 \mathrm{~mL}$. Since this violation rate was greater than the allowable $10 \%$ exceedance rate used for assessing noncompliance, Mill Creek was listed for a bacteria impairment on Virginia's 1998 303(d) impaired waters list. A TMDL to address the bacteria impairment was developed in 2005 by the Center for TMDL and Watershed Studies at Virginia Tech (Benham et al., 2005). Due to a change in state water-quality standards in 2002 (9VAC25-260-170), the Mill Creek TMDL was developed to meet a new E. coli standard, which specifies that the calendar-month geometric mean concentration of $E$. coli shall not exceed $126 \mathrm{cfu}$ $100 \mathrm{~mL}^{-1}$ and that no single sample may exceed a concentration of $235 \mathrm{cfu} 100 \mathrm{~mL}^{-1}$.

\section{Sources of Bacteria}

The bacteria load in the Mill Creek watershed was dominated by agricultural NPS: loads to pasture from livestock, applied manure, and wildlife $(95.8 \%)$; loads to cropland from applied manure and wildlife (1.1\%); and loads to hay land from applied manure and wildlife $(0.96 \%)$. A significant bacteria load also came from cattle $(0.3 \%)$ and wildlife $(0.03 \%$ ) directly depositing feces in Mill Creek and its tributaries. Non-agricultural NPSs of bacteria loadings included sanitary sewer overflows (SSOs) $(0.01 \%)$, household straight pipes $(0.003 \%)$, and residential loads from failing septic systems and pet waste (1.2\%). Although the land-deposited load in upland areas was much greater than in-stream deposition, several factors impacted the amount of bacteria from upland areas that reached Mill Creek. Watershed modeling was performed as part of this TMDL study to consider the effect of these factors when estimating fecal coliform loads to the receiving waters.

\section{Watershed Modeling}

HSPF was used to simulate the fate and transport of fecal coliform bacteria in the Mill Creek watershed. HSPF allows model output to be generated at multiple locations in the watershed, allowing some degree of spatial heterogeneity in simulation. Mill Creek was divided into seven subwatersheds for modeling purposes (fig. 1).

HSPF relies heavily on empirical relationships and must be calibrated. As often occurs in TMDL studies, Mill Creek did not have any flow data available for calibration. Therefore, calibrated hydrologic parameter values from a neighboring watershed, Hawksbill Creek (GMU and Tetra Tech, 2004), were applied to Mill Creek. The resulting hydrologic model was then calibrated for water quality using observed fecal coliform data collected in Mill Creek. For the water-quality simulation, bacteria inputs from loads applied to the land surface were distributed monthly using the Bacteria Source Load Calculator (BSLC) (Zeckoski et al., 2005). The BSLC was also used to generate hourly loads directly deposited to streams. HSPF allows input of land loads as a monthly variable and direct stream loads as an hourly variable. In Mill Creek, as with many small, upland watersheds, HSPF does a poor job of simulating bacteria concentrations at very low stages where, realistically, water tends to collect in pools, and no connected flow occurs. The solution to this problem for Mill Creek was a calibration step that reduced direct deposits by three orders of magnitude when the stream stage fell below $7.6 \mathrm{~cm}$.

A significant permanent drop in observed fecal coliform concentrations occurred in 1998. This drop was due to the closing of a moderate-sized (200 head) dairy operation. Although it is possible to represent land use and bacteria loading changes in HSPF in the midst of a simulation period, this is difficult to implement. Therefore, to appropriately represent the conditions in the watershed, the Mill Creek water-quality calibration was divided into two periods (December 1991-1997 and 1999-2000) with the difference in the periods being the number of animals present in the

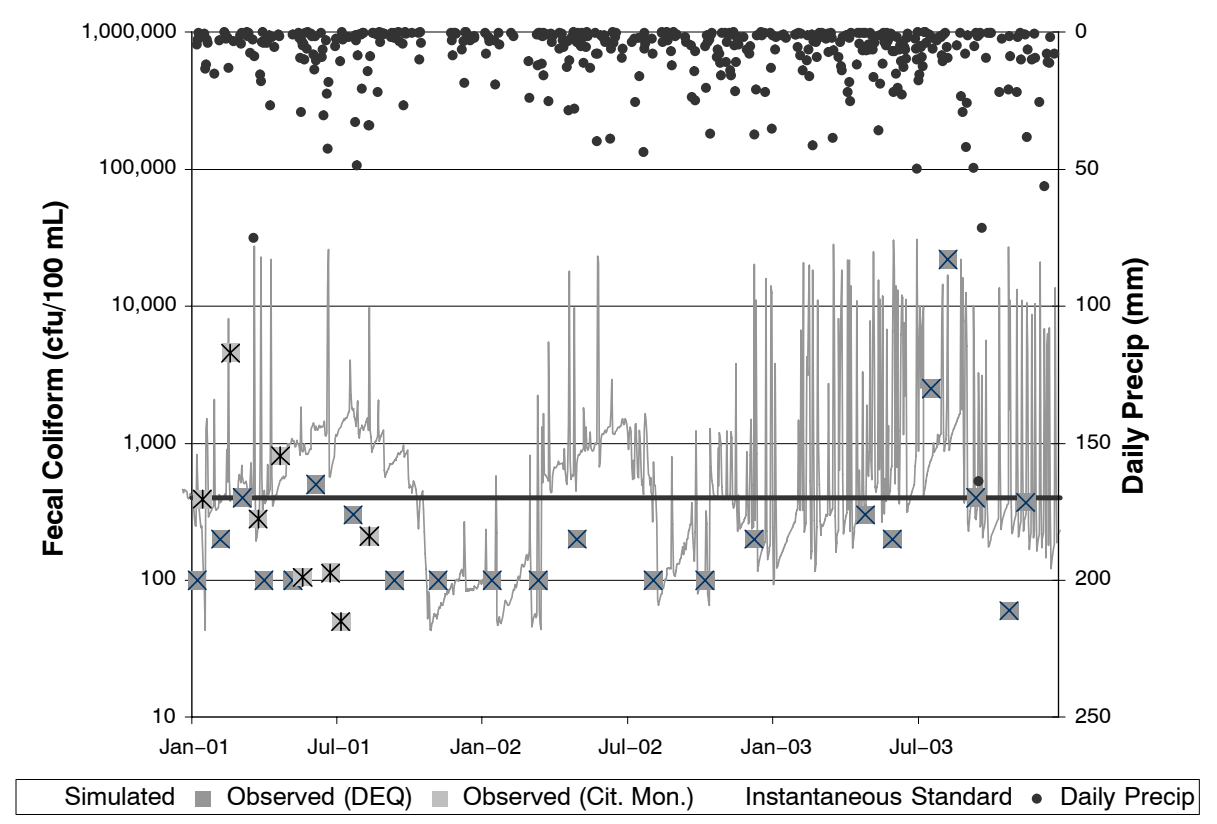

Figure 2. Observed and simulated fecal coliform concentrations for the water-quality validation period (2001-2003). 
watershed. The model was validated (fig. 2) using data collected from 2001-2003 and the number of animals used in the 1999 to 2000 calibration period.

The meteorological period of 1990-2002 was used for the generation of existing condition and allocation scenarios. During this representative period, modeling indicated that $41 \%$ of the mean daily in-stream bacteria concentration came from cattle direct deposits to the stream, 52\% came from upland pervious areas during runoff events, $5 \%$ came from wildlife direct deposits to the stream, and $2 \%$ came from other sources.

\section{TMDL Allocation}

The objective of the TMDL study for Mill Creek was to determine the TMDL bacteria load and the corresponding point- and nonpoint-source load reductions needed to meet state water-quality standards. A series of allocation scenarios that reduced the amount of bacteria applied to the land surface or directly deposited in the stream were simulated until a suitable allocation scenario was found that resulted in zero violations of the state's single-sample and geometric mean numeric criteria (table 3 ).

Scenario 1 in table 3 shows that violations of the single-sample criterion cannot be eliminated even with a $100 \%$ reduction from all non-wildlife bacteria sources. Scenario 2 eliminates all violations of both criteria but would require a $40 \%$ reduction in land-deposited wildlife loads, which are exempted under current state guidelines.

During the summer months, when cattle spend more time in the stream and flows are lower, there is minimal dilution for direct in-stream deposits, leading to violations of the geometric mean standard for bacteria. During rainfall events, the large NPS loadings from upland areas become a major periodic influence on in-stream concentrations, driving the single-sample violations. As no violations of either standard are allowed for the successful allocation scenario, large reductions in both upland loadings and in-stream loadings are typically require in bacteria TMDLs in Virginia. The Mill Creek bacteria impairment TMDL is $8.51 \times 10^{13} \mathrm{cfu}$ year $^{-1} E$. coli. The TMDL includes an implicit margin of safety developed through a conservative calibration of water-quality parameter values. Given that there were no point sources identified in the watershed, the $8.51 \times 10^{13} \mathrm{cfu}$ year $^{-1} E$. coli is also the TMDL load allocation (NPSs only).

\section{Strengths and Weaknesses}

Although HSPF is a lumped parameter model, its ability to divide a watershed into reaches is a strength that allows some degree of spatial heterogeneity in simulation. This feature also allows model output to be generated at multiple locations in the watershed. This is particularly useful in a watershed such as Mill Creek, where multiple water-quality monitoring stations exist within the watershed (fig. 1). The spatial heterogeneity allows bacteria loads to be appropriately distributed throughout the watershed. Additionally, monthly input of bacteria-related parameters permits temporally variable bacteria loadings, allowing the user to represent management practices and migratory behavior. The ability of HSPF to accept hourly loads directly deposited in the stream allows representation of diurnal behavior (e.g., animals that might be housed in a barn at night). Although not used in this study, HSPF's SPEC-ACTIONS block allows a wide range of customization of almost all parameters in the model.

HSPF relies heavily on empirical relationships and must be calibrated. This is a weakness of the model in representing ungauged watersheds such as Mill Creek. In such a case, surrogate parameters from a similar watershed must be used to define the hydrology of the watershed of interest, and these parameters may or may not be adequate. Another limitation of the model is its representation of bacteria concentrations at extremely low flows. At the lowest flows (at or near $0 \mathrm{~m}^{3}$ $\mathrm{s}^{-1}$ ), predicted bacteria concentrations will output an error value $(-1 \mathrm{E}+30)$. Just above zero flow, concentrations become unrealistically large. The user must take steps to prevent or address this weakness for small upland watersheds such as Mill Creek. Although SPEC-ACTIONS can be used to address such problems, and is in one sense a strength of HSPF, it is also a weakness because the use of SPEC-ACTIONS for this or other customizations (such as the detailed description of BMPs) is not straightforward.

Bacteria loads to HSPF must be calculated externally to the model, often with the aid of a program such as the BSLC or the BIT. The detail required to use these tools encourages modelers to interact closely with stakeholders and agency personnel to completely describe the watershed in question during a TMDL study. The collected watershed details are used both in modeling and in the writing of the report, and provide significant information when developing implementation plans.

Table 3. Bacteria allocation scenarios for the Mill Creek watershed.

\begin{tabular}{|c|c|c|c|c|c|c|c|c|c|c|}
\hline & \multicolumn{2}{|c|}{$\begin{array}{c}\text { Violation of WQS[a] } \\
\text { Criteria }(\%)\end{array}$} & \multicolumn{8}{|c|}{ Bacteria Load Reductions from Sources $(\%)$} \\
\hline & $\begin{array}{c}\text { Geometric } \\
\text { Mean } \\
(126 \mathrm{cfu} \\
\left.100 \mathrm{~mL}^{-1}\right)\end{array}$ & $\begin{array}{c}\text { Single } \\
\text { Sample } \\
(235 \mathrm{cfu} \\
\left.100 \mathrm{~mL}^{-1}\right)\end{array}$ & $\begin{array}{l}\text { Sanitary } \\
\text { Sewer } \\
\text { Overflow }\end{array}$ & $\begin{array}{l}\text { Straight } \\
\text { Pipes }\end{array}$ & $\begin{array}{c}\text { Failed } \\
\text { Septic } \\
\text { Systems }\end{array}$ & $\begin{array}{l}\text { Livestock } \\
\text { Direct } \\
\text { Deposit }\end{array}$ & $\begin{array}{l}\text { Manure on } \\
\text { Agriculture } \\
\text { PLS }[\mathrm{b}]\end{array}$ & $\begin{array}{l}\text { Residential[d] } \\
\text { PLS + ILS[e] }\end{array}$ & $\begin{array}{l}\text { Forest }[\mathrm{f}] \\
\text { PLS }\end{array}$ & $\begin{array}{c}\text { Wildlife } \\
\text { Direct } \\
\text { Deposit }\end{array}$ \\
\hline $\begin{array}{l}\text { Existing } \\
\text { Conditions }\end{array}$ & 95 & 60 & 0 & 0 & 0 & 0 & 0 & 0 & 0 & 0 \\
\hline Scenario 1 & 0 & 0.02 & 100 & 100 & 100 & 100 & 100 & 100 & 0 & 0 \\
\hline Scenario $2^{[\mathrm{g}]}$ & 0 & 0 & 100 & 100 & 100 & 100 & 100 & 100 & 40 & 0 \\
\hline $\begin{array}{ll}\text { [a] } & \text { WQS = wat } \\
\text { [b] } & \text { Loads to ag } \\
\text { [c] } & \text { PLS = perv } \\
\text { [d] } & \text { Loads to re } \\
\text { [e] } & \text { ILS = impe } \\
\text { [f] } & \text { Loads to fo } \\
\text { [g] } & \text { Successful }\end{array}$ & $\begin{array}{l}\text {-quality stan } \\
\text { ultural land } \\
\text { is land segm } \\
\text { ential land s } \\
\text { ous land seg } \\
\text { t land segme } \\
\text { LDL allocati }\end{array}$ & $\begin{array}{l}\text { dd. } \\
\text { ments origir } \\
\text { (e.g., pastur } \\
\text { nents origin } \\
\text { nt (e.g., side } \\
\text { originate fr } \\
\text { scenario (res }\end{array}$ & $\begin{array}{l}\text { om livestoc } \\
\text { pland, fores } \\
\text { om humans } \\
\text { pavement) } \\
\text { ildlife. } \\
\text { n zero viola }\end{array}$ & d pets. & ble wat & uality st & dard criteria) & ank & & \\
\hline
\end{tabular}




\section{SWat Case Study: Shoal Creek Fecal Coliform TMDL \\ Watershed Description}

The Shoal Creek watershed covers $367 \mathrm{~km}^{2}$ in southwest Missouri (fig. 3). Ninety percent is comprised of pastures grazed by cattle and fertilized by poultry litter; the remainder is forested. The watershed is located in a region of karst hydrology with features such as springs, sinkholes, and losing streams. All rural citizens in the watershed use septic systems. A $21.6 \mathrm{~km}$ long segment of Shoal Creek is designated impaired due to high fecal coliform concentrations.

\section{Water-Quality Impairment}

Fecal coliform concentrations were monitored from June 2001 through October 2003, with weekly sampling during the recreation season (April to October) and monthly sampling during the rest of the monitoring period. The geometric mean concentration of samples collected during the recreation season violated the water-quality criterion of $200 \mathrm{cfu}$ $100 \mathrm{~mL}^{-1}$, and $30 \%$ of the samples exceeded the single-sample fecal coliform criterion of $400 \mathrm{cfu} 100 \mathrm{~mL}^{-1}$.

\section{Sources of Bacteria}

Given the rural nature of the watershed, the following sources were considered when characterizing bacteria loading in the watershed: septic tanks and illegal connections, poultry litter, grazing cattle, and wildlife. Bacteria source tracking was accomplished by DNA fingerprinting using the rep-PCR method (Carson et al., 2003; Dombek et al., 2000). Results were examined according to season and as a function of flow. Bacteria source tracking indicated that nearly $50 \%$ of fecal pollution was attributed to cattle during summer and $25 \%$ during winter. The combined contribution from poultry, horse, and $\operatorname{dog}$ varied between $13 \%$ and $18 \%$ of total pollution. Human contribution ranged between $11 \%$ and $21 \%$. Cattle manure and poultry litter used as fertilizer were associated with high fecal coliform counts recorded during storms. Human and wildlife sources were more prominent during winter. Additional monitoring of a spring showed that groundwater is an important transport mechanism for bacteria moving from the ground surface to the stream.

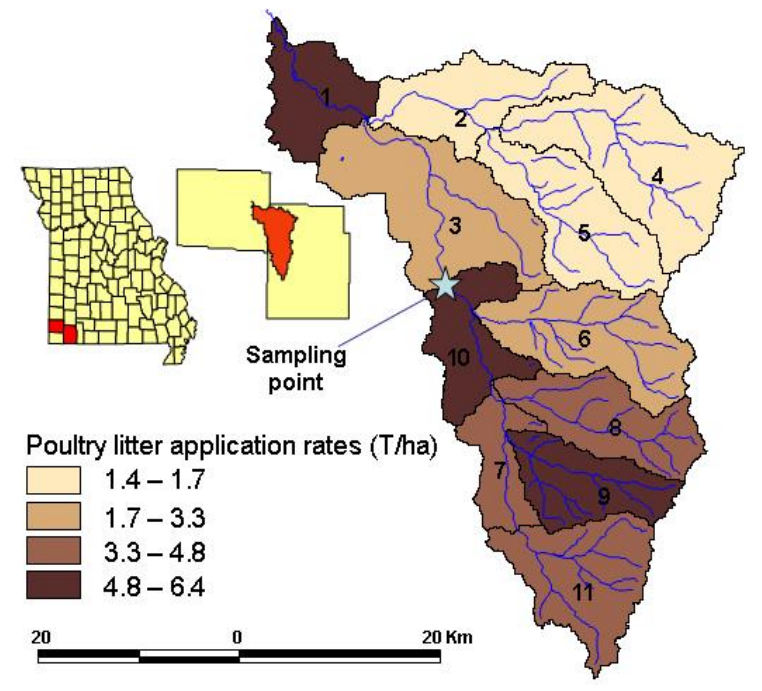

Figure 3. Poultry litter application rates in the Shoal Creek watershed, by subbasin.

\section{Watershed Modeling}

The Shoal Creek watershed model was developed using SWAT2000 and the AVS2000 Arc View interface (Baffaut, 2004). GIS data include a $30 \mathrm{~m}$ resolution digital elevation map, a $30 \mathrm{~m}$ resolution Soil Survey Geographic (SSURGO) soil map with SSURGO soil characteristics, and $30 \mathrm{~m}$ resolution land use and land cover map. Soil parameters for complex soils were derived as a weighted average of the soil components. Climatic parameters were obtained from two local weather stations. The watershed was divided into 11 subwatersheds in order to uniquely characterize each tributary. This discretization allowed specification of poultry litter application rates that reflected the density of poultry operations and the quantity of available pasture acres in each subwatershed.

Information on management practices in the watershed was gathered during meetings with a watershed steering committee. A panel of producers provided information on the type and timing of operations performed on the pasture areas. Rotation management on pasture areas included grazing and resting periods, hay harvest, and poultry litter and nitrogen applications. Grazing densities and durations were adjusted between different pasture grades to account for all the cattle in the watershed, the acres available for grazing, and the seasonal fescue growth rates. Poultry litter was applied on the pastures between February and March at rates proportional to the amount of litter available in the subwatershed. Deer were set to graze in forest land at densities estimated from annual kill numbers.

Cattle were simulated as contributing a portion of their bacteria loads directly to streams. These amounts were estimated from the number of cattle with access to streams and the fraction of their daily waste deposited in the stream. Septic tanks for housing units located within $90 \mathrm{~m}$ of a stream were also regarded as direct discharges, while other septic tanks were not considered to be contributing sources. A new version of the SWAT model has an option to represent septic tanks as a daily fertilizer application over a given duration (e.g., Pradhan et al., 2005).

The irrigation of land with effluent from a poultry processing plant was simulated as continuous irrigation along with a modification of the code to specify the bacteria concentration of this special irrigation water.

The model was calibrated based on more than two years of daily flow values measured at a flow gauge located in the middle of the watershed. The flow measurements were made over two time periods with a one-year interruption in between. The calibration was performed manually by adjusting one parameter at a time, running the model, and then evaluating the model results with visual comparison of the hydrographs and five calibration criteria: average annual flow, daily and monthly correlation coefficients, and daily

Table 4. Calibration measures for the Shoal Creek watershed.

\begin{tabular}{lccc}
\hline Criteria & $\begin{array}{c}\text { Calibration } \\
\text { Criteria }\end{array}$ & $\begin{array}{c}\text { Calibration Period } \\
\text { (May 1999 } \\
\text { to June 2000) }\end{array}$ & $\begin{array}{c}\text { Validation Period } \\
\text { (June 2001 } \\
\text { to Sept. 2002) }\end{array}$ \\
\hline Overall difference & $\pm 10 \%$ & $12 \%$ & $-4 \%$ \\
Monthly R $^{2}$ & $\geq 0.6$ & 0.70 & 0.66 \\
Monthly NSE[a] $^{2}$ & $\geq 0.6$ & 0.63 & 0.61 \\
Daily R & $\geq 0.5$ & 0.40 & 0.61 \\
Daily NSE & $\geq 0.5$ & 0.21 & 0.54 \\
\hline
\end{tabular}

[a] Nash-Sutcliffe efficiency coefficient. 


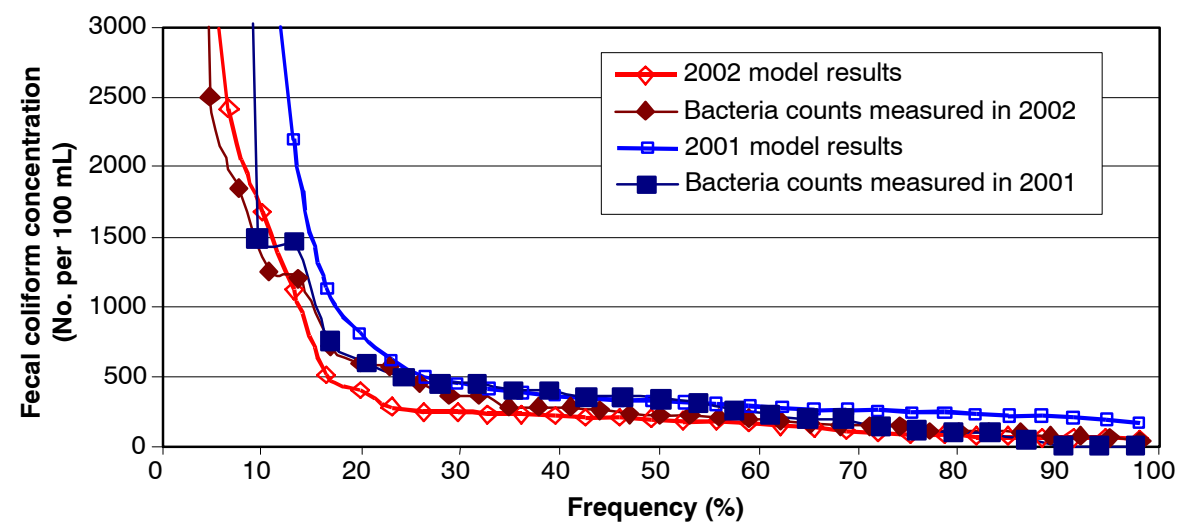

Figure 4. Frequency curve of measured and simulated fecal coliform concentrations.

and monthly Nash-Sutcliffe efficiency coefficients (NSE). The final results of the calibration are presented in table 4.Even though all calibration criteria were not satisfied for the calibration period (May 1999 to June 2000), a visual comparison of the simulated and observed hydrographs indicated that the model was simulating the system satisfactorily. Possible reasons why the model performance criteria were not met include a very dry year combined with flows sustained by karst features not represented in SWAT. All calibration criteria were met for the validation period (June 2001 to Sept. 2002).

Model parameters related to bacteria were adjusted on the basis of concentration frequency curves (fig. 4). Only the simulated values for the days when a sample was collected were considered. The waste directly deposited in the streams (cattle and septic tanks) was adjusted by fitting bacteria concentration during base-flow conditions. Two series of measurements taken at two stream locations were used to calculate an average stream die-off coefficient of 2.01 days $^{-1}$.

\section{TMDL Allocation}

Once calibrated, the model was used to calculate the contribution from each source of bacteria, how often the stream was out of compliance, and the in-stream load. In order to evaluate load reduction options, the following BMPs were simulated: edge-of-field buffers to reduce NPS loading to the streams, stream exclusion fencing to reduce direct deposits from cattle, and elimination of illegal septic discharges through enforcement, education, and septic tank pumping. Several scenarios specifying different levels of bacteria source reduction were run in order to assess which suite of management practices would lead the stream meeting the applicable state water-quality criteria, which specify that the 30-day geometric mean concentration of fecal coliform shall not exceed $200 \mathrm{cfu} 100 \mathrm{~mL}^{-1}$ and that fewer than $10 \%$ of the samples may exceed a concentration of $400 \mathrm{cfu} 100 \mathrm{~mL}^{-1}$ (table 5).

None of the scenarios met both criteria. Scenarios 3 and 4 met the single-sample water-quality criterion but not the geometric mean criterion. The recommendation was to first address the contamination from human sources because it presents the largest health danger to humans, then to eliminate cattle from the streams by providing alternative drinking sources and shaded areas, and finally to implement buffers and filter strips. Fencing was not recommended because of its limited attractiveness to producers and the potential for fences washing out during flood events. A last possibility not addressed in the TMDL was to compost the poultry litter to reduce its bacterial load or to transport it out of the watershed. This alternative was not favored by the steering committee at the time because alternative fertilizers would have to be purchased to sustain grazing densities.

The Shoal Creek bacteria-impairment TMDL is $2.75 \times$ $10^{11}$ fecal coliform cfu day ${ }^{-1}$. The TMDL includes both an implicit margin of safety developed through a conservative calibration of hydrologic parameter values and an explicit margin of safety of $1.75 \times 10^{11} \mathrm{cfu}^{-1 a y^{-1}}$ that takes into account the natural variation of the flows caused by climatic variability. One small permitted source is allocated a load of $4.54 \times 10^{8}$ cfu day $^{-1}$.

\section{Strengths and Weaknesses}

The representation of management practices in SWAT provided a simple method to release bacteria in and on the soil and in the water. It allowed the specification of each source within the individual management operations. A weakness of the model was the representation of the ground-

Table 5. Bacteria allocation scenarios for the Shoal Creek watershed.

\begin{tabular}{|c|c|c|c|c|c|c|c|}
\hline & \multicolumn{2}{|c|}{ Violation of WQS ${ }^{[\mathrm{a}]}$ Criteria (\%) } & \multicolumn{5}{|c|}{ Bacteria Load Reductions from Sources (\%) } \\
\hline & 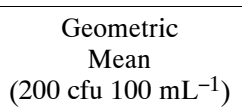 & $\begin{array}{c}\text { Single } \\
\text { Sample } \\
\left(400 \mathrm{cfu} 100 \mathrm{~mL}^{-1}\right)\end{array}$ & $\begin{array}{l}\text { Straight } \\
\text { Pipes }\end{array}$ & $\begin{array}{l}\text { Failed } \\
\text { Septic } \\
\text { Systems }\end{array}$ & $\begin{array}{l}\text { Livestock } \\
\text { Direct } \\
\text { Deposits }\end{array}$ & $\begin{array}{l}\text { Poultry } \\
\text { Litter on } \\
\text { Pastures }\end{array}$ & $\begin{array}{l}\text { Grazing } \\
\text { on } \\
\text { Pastures }\end{array}$ \\
\hline $\begin{array}{c}\text { Existing } \\
\text { Conditions }\end{array}$ & 82 & 30 & 0 & 0 & 0 & 0 & 0 \\
\hline Scenario 1 & 20 & 12 & 100 & 100 & 50 & 50 & 50 \\
\hline Scenario 2 & 9 & 10 & 100 & 100 & 100 & 50 & 50 \\
\hline Scenario 3 & 15 & 8 & 100 & 100 & 50 & 66 & 66 \\
\hline Scenario 4 & 8 & 7 & 100 & 100 & 100 & 66 & 66 \\
\hline
\end{tabular}

[a] WSQ = water-quality standard. 
water processes in a karst environment. During the dry spell of 2001, the flows of Shoal Creek were sustained by the groundwater flow, which was difficult to simulate with SWAT. SWAT assumed no transport of bacteria through the soil profile and with groundwater. While a point discharge can have a bacterial load associated to it, groundwater was assumed to be free of bacteria, which was not verified by monitoring. However, the processes that control bacteria survival and movement in the soil and in groundwater need to be better understood before they can be modeled and incorporated in a watershed-scale NPS model.

The Shoal Creek SWAT model developed for the purpose of calculating the TMDL provided a tool to investigate load allocation scenarios suggested by the watershed committee. More importantly, the TMDL process provided education and communication opportunities between the watershed stakeholders and the modelers. As management information and feedback was provided by producers, scientific and technical information was presented by modelers. The development of the model provided the basis for these exchanges because of the information that the modeling exercise requires and provides. Stakeholders who were part of the watershed committee became very involved in a watershed group that was formed to address TMDL implementation, the next step in the TMDL process.

\section{Load-Duration Case Study: Kansas River at LECOMPTON Watershed Description}

The Kansas River, in northeast Kansas, drains $151,400 \mathrm{~km}^{2}$ at Lecompton, of which $86 \%$ is regulated by six federal reservoirs, leaving approximately $21,000 \mathrm{~km}^{2}$ of uncontrolled drainage contributing to flow. The land use is predominantly an agricultural mix of cropland and grazing lands, with a few major cities dotting the length of the river. The major discharger to the river is Topeka, located $31 \mathrm{~km}$ above Lecompton. Until 2003, wastewater from Topeka was not disinfected.

\section{Water-Quality Impairment}

Fecal coliform bacteria samples have been taken from a monitoring site at Lecompton since 1985, typically on a bimonthly schedule. The 1998 303(d) list of impaired waters included the Kansas River at this location because of sufficient frequency of violations over the primary recreation criterion of $200 \mathrm{cfu} 100 \mathrm{~mL}^{-1}$ and the secondary criterion of $2000 \mathrm{cfu} 100 \mathrm{~mL}^{-1}$, applicable from November to March. The USGS also maintains a long-term gauging station at this location, measuring streamflow continuously.

\section{River Analysis and TMDL Application}

The load-duration method was applied to the watershed draining to the Kansas River at Lecompton. Fecal coliform bacterial TMDL limit lines for this stream segment were set at $200 \mathrm{cfu} 100 \mathrm{~mL}^{-1}$ for primary contact recreation and 2000 cfu $100 \mathrm{~mL}^{-1}$ for secondary contact recreation, shown as continuous lines in figure 5. Comparison of the daily sampled bacterial loads to the upper-bound TMDL limit lines (fig. 5) shows that exceedances of both primary and secondary contact criteria occurred during all hydrologic flow conditions prior to establishing the TMDL in 1999. This loadduration curve demonstrated contributions of both point sources (during low-flow, high exceedance-percentage conditions) and nonpoint sources (during higher-flow conditions). Initial (2000-2002) post-TMDL loads show some improvement at lower flows, possibly reflecting pervasive drought conditions, but continued exceedances occurred during runoff events. After upgrades in late 2002 to Topeka's major wastewater treatment plant, located above the monitoring station, fewer exceedances were observed during low-flow conditions as a result of wastewater disinfection, although exceedances remained for the high-flow conditions. Hence, further efforts to reduce bacterial loads in this watershed should focus on abating NPS bacterial sources. The method also indicates compliance with criteria for bacteria water quality during lower flows when in-stream recreation is more likely.

\section{Strengths and Weaknesses}

The load-duration method provides a rapid, visual assessment of water-quality conditions and their underlying

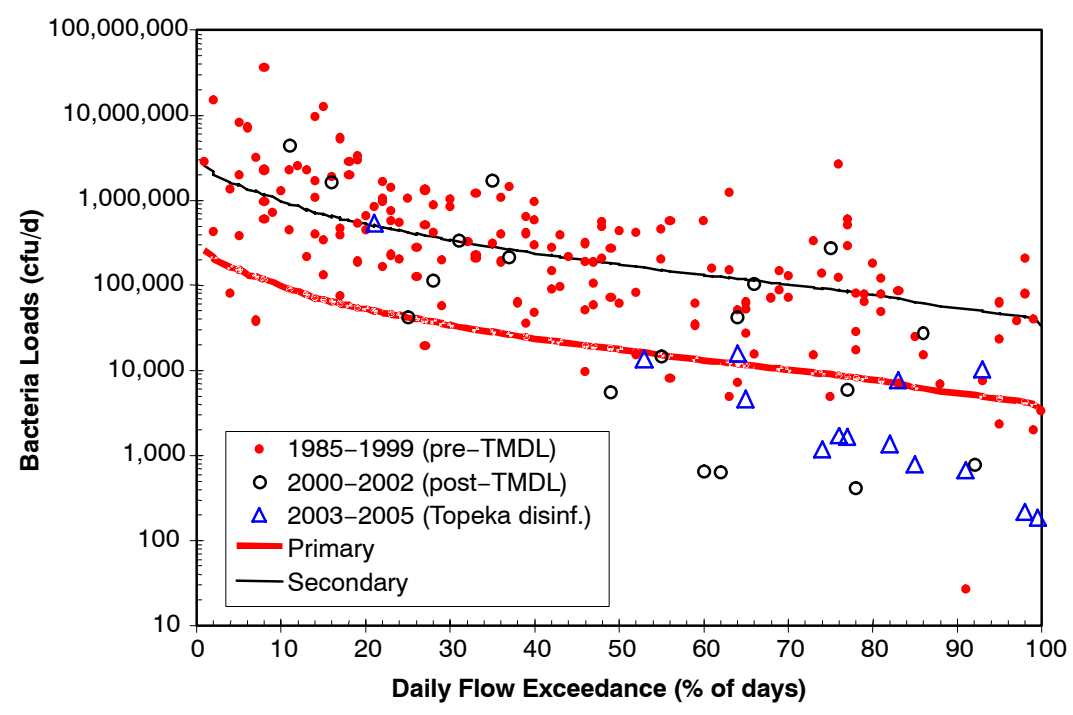

Figure 5. Flow-duration analysis of fecal coliform bacteria loads for the Kansas River at Lecompton before (closed circles) and after (open circles) establishment of a TMDL in 1999, and after initiation of wastewater disinfection at Topeka (open triangles) in 2003 (modified from KDHE, 2006). 
flow conditions. A quantitative expression of permissible bacteria loading can be obtained by integrating the area under the TMDL curve. A quantified estimate of current condition loading could be obtained by developing a regression line of bacteria loads based on flow exceedance percentage. Comparison of the regression line with the TMDL can provide an estimate of necessary load reduction to achieve water-quality standards and the hydrologic conditions to be targeted for management. The method also provides a baseline against which post-TMDL conditions may be compared in order to evaluate the effectiveness of implementation activities in abating bacteria loads.

The method is weak in delineating the transition between point-source and NPS loadings. As a result, derivation of the necessary wasteload allocations and load allocations is somewhat arbitrary. In addition, load-duration curves present the integrated response from the entire watershed above the monitoring station, but provide no information on loading and sources within the watershed. Therefore, the load-duration curve is a good representation of overall water quality and necessary improvement, but intra-watershed contributions must be determined through supplemental sampling upstream or through simulation modeling relating land use and hydrologic response to bacterial loadings.

\section{RESEARCH NEEDS}

\section{IMPROVED SOURCE CHARACTERIZATION}

Although bacteria concentrations in feces and some animal habitat and behavioral information can be gleaned from the literature, this type of information is scarce. As was mentioned in a footnote to table 1, wildlife populations used when developing bacteria-impairment TMDLs are often estimated indirectly. Much of the information on bacteria density in feces reported in the literature is not the focus of the reported research and thus has not undergone thorough peer review. The source characterization process for bacteria impairment TMDLs would benefit from research specifically focused on collecting behavior pattern, habitat, and population density data and determining accurate estimates of species-specific bacteria production and variability. Behavior pattern research should include investigation of the fraction of time spent in the water, changes in behavior patterns with changes in flow, and preferential defecation locations. A further investigation into the relationships between fecal bacteria content and latitude, elevation, diet, and water source for all species (human, livestock, and wildlife) would also provide valuable information for source characterization during development of bacteria-impairment TMDLs.

Except for intensive field inventories, methods to determine the number of failing septic systems or straight pipes in a watershed are somewhat subjective. A statistical evaluation of domestic sewage systems throughout the nation might provide more realistic and defensible estimates of these human sources. Factors in such an evaluation might include income levels, education, age of communities, type of soil, and physiographic region.

\section{Modeling Advances}

Considering the state of current bacteria models, we have identified four major categories of improvements or modifications: (1) better representation of bacteria life cycle and processes; (2) inclusion of more appropriate fate and transport processes (e.g., sorption and release on land and in water, preferential flow); (3) incorporation of procedures to improve simulation of catastrophic conditions, or rare events; and (4) creation of a decision support tool (DST) to aid users in selecting an appropriate model or method to fit their circumstances and meet their objectives.

There are several key processes in existing models that should be improved to increase our understanding of bacteria fate and transport. These processes can be grouped into three general categories: sediment-attached bacteria and corresponding deposition, resuspension, and partitioning; die-off and re-growth of bacteria; and non-linearity of bacteria fate and transport. In-stream bacterial populations have been shown to increase by nearly a factor of 400 after agitation of stream channel sediment (DeGuise and Mostaghimi, 2000), indicating that stream sediment is a reservoir of bacteria. Processes such as settling, re-suspension, and resettling need to be incorporated into existing models. The partitioning of bacteria among vegetation, sediment-attached, free-associated, and microbial slime pools needs to be better understood and simulated. The effect of soil texture and the presence of manure or other nutrient sources on partitioning also need to be quantified (Mankin et al., 2006b). Research is also needed to establish settling and re-suspension rates of bacteria transported in overland flow.

Bacteria are living organisms and their survival needs to be better quantified in models. Estimates of bacteria densities "as excreted" often do not accurately reflect the amount of bacteria available to be transported by runoff events; bacteria populations undergo a dramatic decrease of nearly two orders of magnitude between manure storage and field application (DeGuise and Mostaghimi, 2000). At the same time, a substantial re-growth of bacteria populations has been observed following land application of manure or deposition by livestock (Crane et al., 1980; Wang et al., 2004) and needs to be quantified. More accurate relationships are also needed to describe the effects of manure incorporation on bacteria survival and transport.

It is critical to better understand how the nonlinearities observed in release, retention, and transport of bacteria manifest themselves at finer scales to be able to accurately represent bacteria behavior at the watershed scale. Furthermore, watershed-scale models have difficulty simulating spatially and temporally rare events. An effort is needed to incorporate a probabilistic description of rare events into models of coarse scale. Current watershed-scale models predict bacteria loads proportional to the average water flow and bacteria concentration. In actuality, a wide distribution of runoff velocities and flows exists throughout the watershed. As a result, some bacteria are transported to the stream much earlier or much later than average runoff flow rates suggest.

A DST would be useful for both new and existing modelers in selecting appropriate models for simulating bacteria fate and transport. This DST might include questions such as: (1) what is (are) the pathogen(s) or indictor(s) of concern; (2) what type and methods of manure application are to be represented; (3) are there other primary sources of bacteria within the watershed; (4) are vegetative buffers or riparian systems or both present; (5) are in-stream processes significant; (6) what type of geologic formations exist, and what is the importance of the groundwater component; 
(7) what scale is to be simulated; (8) what monitoring data are available to calibrate the model; (9) what level of detail is available to characterize bacteria loading; and (10) what meteorological data are available? Answers to these questions in the new DST would help guide a model user in selection of a proper model for his or her objectives.

Despite the large number of field-scale studies attempting to quantify the concentrations and loads of fecal bacteria in runoff from agricultural lands (Crowther et al., 2002; Edwards et al., 1994; Edwards et al., 2000; Khaleel et al., 1980; Mankin et al., 2006a; Schepers and Doran, 1980; Soupir et al., 2006; Tian et al., 2002), our understanding of natural variability and factors influencing microbial transport is still rudimentary (Jamieson et al., 2004). Pathogens or indicator organisms on the land surface may contaminate surface waters through movement with surface runoff (either attached to sediment and organic particles or in the planktonic state) and groundwater through downward leaching with infiltrating water (Reddy et al., 1981). Often, infiltration into the soil has not been monitored, and partitioning between attached and planktonic forms during surface runoff has not been considered. The three commonly observed patterns of indicator bacteria die-off are first-order decay, bacteria growth followed by first-order decay, and first-order decay with variable die-off rates (Crane and Moore, 1986; Mancini, 1978). Since very little is actually known about the individual influences and interactions between the many parameters affecting die-off, first-order decay is most often used to express bacterial die-off. However, researchers are finding that improved equations are needed to better capture the bacterial survival dynamics for extended periods (Wang et al., 2004; Mankin et al., 2006b).

Most current models completely ignore the subsurface transport of bacteria (Jamieson et al., 2004) and typically simulate bacterial transport to surface waters as a dissolved pollutant (Paul et al., 2004). The interactions between bacteria and sediment particles during overland flow events have received little attention. Previous studies have determined that fecal bacteria preferentially attach to particulate matter (Auer and Niehaus, 1993; Henry, 2004; Ling et al., 2002); however, it is unknown if this attachment occurs on the land, during runoff events, or during in-stream processes. SWAT is the only watershed-scale NPS model that attempts to partition between the planktonic and attached phases, but reliable data on bacteria partitioning are currently not available (Jamieson et al., 2004).

\section{Stochastic Modeling Approaches}

Inclusion of stochastic modeling approaches in the development of TMDLs would provide regulators and stakeholders with additional alternatives, such as the ability to incorporate risk-based analysis in conjunction with allocation scenarios. Currently, most TMDLs established through modeling are derived based on a deterministic approach. Deterministic models use fixed input parameters to predict an outcome. Given the same input parameters and boundary conditions, a deterministic model will always predict the same outcome. This approach is very limiting considering all the uncertainties involved in the TMDL process. In addition, the risk posed to stakeholders is unknown, since an assessment of risk is not possible with only one time-series of bacteria concentrations. Both HSPF and SWAT are deterministic models. An alternative to the deterministic approach would be to incorporate stochastic methods in the modeling of the impaired waterbody.

Probabilistic or stochastic models use a statistical distribution of possible input parameters and boundary conditions and consequently result in a statistical distribution of possible outcomes. While a stochastic representation of all model inputs may not be possible in most cases, a subset of input parameters could be treated as random variables while others as constants. A simpler alternative is to hold all the input parameters constant and to perform Monte Carlo simulations (a commonly used stochastic technique) using randomly generated climate data. In all of these approaches, multiple time-series outputs are generated and can be used for relevant statistical analyses and risk analysis. This approach has not been used in studies on TMDL development to date, but it could be incorporated into the TMDL development process with further research and development of the needed tools. Shirmohammadi et al. (2006) address model uncertainty in greater detail in a companion article.

\section{SumMary AND CONCluSions}

Fecal contamination of surface waters is a critical waterquality issue, leading to human illnesses and deaths. Total Maximum Daily Loads (TMDLs) for bacteria impairments often require the use of watershed modeling tools to assess bacteria impairments, define bacteria sources and loads, and guide remediation efforts. In this way, watershed models are widely used to support TMDLs, although their use for fecal bacteria simulation is somewhat rudimentary. This article presented an overview of the concepts, tools, and methods currently used to develop TMDLs for bacteria impairments. Two NPS watershed models (HSPF and SWAT) and the load-duration method were reviewed for use in setting target TMDL loads and were illustrated with case studies.

Both HSPF and SWAT permit the user to discretize the watershed spatially and to define bacteria loads temporally. However, the options and flexibilities are limited. The models are also limited in their ability to describe bacterial life cycles and their ability to adequately simulate bacteria concentrations during extreme climatic conditions. Even with their limitations, these models are beneficial in helping develop TMDLs because the source characterization activities needed to define inputs for the models provide educational opportunities for both stakeholders and modelers alike throughout the TMDL process. The load-duration method for developing TMDLs provides a good representation of overall water quality and needed water quality improvement, but intra-watershed contributions must be determined through supplemental sampling or through subsequent modeling relating land use and hydrologic response to bacterial concentrations.

Substantial additional research is needed to improve the methods and models used to develop bacteria-impairment TMDLs. Regardless of the tool or method used to develop these TMDLs, accurate characterization of bacteria sources and load quantification is needed. Improved source characterization needs include better estimates of animal populations, fecal production, indicator-bacteria density, indicator-bacteria release rates from feces, and indicator-bacteria survivability. Four major categories of improvements or modifications for models used in bacteria simulation were identified: (1) better representation of bacteria life cycle and processes; (2) inclusion of more appropriate fate and transport processes (e.g., sorption and 
release on land and in water); (3) incorporation of procedures to improve simulation of catastrophic conditions, or rare events; and (4) creation of a decision support tool (DST). In addition, the application of stochastic modeling approaches is needed to provide assessments of model uncertainties associated with simulated bacteria concentrations. Finally, continued research is needed to relate sources, fate, and transport of fecal pathogens to the more-common and readily modeled indicator bacteria. Such improvements would result in more-reliable, source-specific bacteria estimates that would allow watershed decision makers to optimize time, money, and effort invested in water-quality remediation and protection efforts.

\section{ACKNOWLEDGEMENTS}

This article is the one of a series of articles developed by members of the USDA-CSREES Regional Project S-1004 "Development and Evaluation of TMDL Planning and Assessment Tools and Processes" and the ASABE SW-21 Hydrology Committee. The authors would like to acknowledge the editorial leadership and coordination provided by Rafael Muñoz-Carpena, Adel Shirmohammadi, and George Vellidis in this group effort. The authors also wish to thank Drs. Gene Yagow and George Vellidis for their suggestions that helped improve the manuscript.

\section{REFERENCES}

Alderisio, K. A., and N. DeLuca. 1999. Seasonal enumeration of fecal coliform bacteria from the feces of ring-billed gulls (Larus delawarensis) and Canada geese (Branta canadensis). Applied and Environ. Microbiol. 65(12): 5628-5630.

Arnold, J. G., and N. Fohrer. 2005. SWAT2000: Current capabilities and research opportunities in applied watershed modeling. Hydrol. Process. 19(3): 563-572.

ASAE Standards. 1998. D384.1: Manure production and characteristics. St Joseph, Mich.: ASAE.

Auer, M. T., and S. L. Niehaus. 1993. Modeling fecal coliform bacteria: I. Field and laboratory determination of loss kinetics. Water Research 27(4): 693-701.

Baffaut, C. 2004. Upper Shoal Creek watershed water quality analysis. FAPRI-UMC Report No. 01-04. Columbia, Mo.: University of Missouri, Food and Agricultural Policy Research Institute. Available at: www.fapri.missouri.edu/outreach/ publications/2004/FAPRI_UMC_Report_01_04.pdf. Accessed 19 December 2005.

Bengtsson, G. 1989. Growth and metabolic flexibility in groundwater bacteria. Microb. Ecol. 18(3): 235-248.

Bengtsson, G., and R. Lindqvist. 1995. Transport of soil bacteria controlled by density-dependent sorption kinetics. Water Resources Research 31(5): 1247-1256.

Benham, B., G. Yagow, B. Barham, R. Zeckoski, and T. Dillaha. 2005. Total Maximum Daily Load Development: Mill Creek bacteria (E. coli) impairment, Page County, Virginia. Richmond, Va.: Virginia Department of Environmental Quality. Available at: www.deq.virginia.gov/tmdl/apptmdls/shenrvr/millpage.pdf. Accessed 11 November 2005.

Bicknell, B., J. Imhoff, J. Kittle, Jr., A. Donigan, and R. Johanson. 1997. Hydrological Simulation Program FORTRAN. User's Manual for Version 11. EPA/600/R-97/080. Research Triangle Park, N.C.: USEPA National Exposure Research Laboratory.

Borah, D. K., and M. Bera. 2003. Watershed-scale hydrologic and nonpoint-source pollution models for long-term continuous and storm event simulations. In Total Maximum Daily Load (TMDL) Environmental Regulations II, 161-167. ASAE Publication 701P1503. St. Joseph, Mich.: ASAE.
Bradford, S. A., and J. F. Schijven. 2002. Release of Cryptosporidium and Giardia from dairy calf manure: Impact of solution salinity. Environ. Sci. Tech. 36(18): 3916-3923.

Carson, C. A., B. L. Shear, M. R. Ellersiek, and J. D. Schnell. 2003. Comparison of ribotyping and repetitive extragenic palindromic-PCR for identification of fecal Escherichia coli from humans and animals. Applied and Environ. Microbiol. 69(3): 1836-1839.

Crane, S. R., and J. A. Moore. 1986. Modeling enteric bacterial die-off: A review. Water, Air, and Soil Poll. 27(3-4): 411-439.

Crane, S. R., P. W. Westerman, and M. R. Overcash. 1980. Die-off of fecal indicator organisms following land application of poultry manure. J. Environ. Qual. 9(3): 531-537.

Crowther, J., D. Kay, and M. D. Wyer. 2002. Faecal-indicator concentrations in waters draining lowland pastoral catchments in the U.K.: Relationships with land use and farming practices. Water Research 36(7): 1725-1734.

Curriero, F. C., J. A. Patz, J. B. Rose, and S. Lele. 2001. The association between extreme precipitation and waterborne disease outbreaks in the United States, 1948-1994. American J. Public Health 9(8): 1194-1199.

Cuthbert, W. A., J. J. Pane, and E. C. Hill. 1955. Survival of bacterium coli type I and Streptococcus faecalis in soil. $J$. Applied Microbiol. 12: 63-70.

DeGuise, K., and S. Mostaghimi. 2000. Bacterial die-off rate constant and partitioning coefficient determination. Final Project Report prepared for the Virginia Department of Conservation and Recreation, Richmond, Va.

Dombek, P. E., L. K. Johnson, S. J. Zimmerley, and M. J. Sadowsky. 2000. Use of repetitive DNA sequences and the PCR to differentiate Escherichia coli isolates from human and animal sources. Applied and Environ. Microbiol. 66(6): 2572-2577.

Donigian, A. S., W. C. Huber, and T. O. Barnwell. 1991. Modeling of nonpoint-source water quality in urban and non-urban areas. EP1.23:600/3-91/039. Athens, Ga.: USEPA Environmental Research Laboratory, Office of Research and Development.

Drapcho, C. M., and A. K. B. Hubbs. 2003. Fecal coliform concentration in runoff from fields with applied dairy manure. Available at: www.lwrri.lsu.edu/downloads/Drapcho_ annual\%20report01-02.pdf. Baton Rouge, La.: Louisiana State University Agricultural Center. Accessed 16 December 2005.

Edwards, D. R., T. C. Daniel, P. A. Moore, Jr., and A. N. Sharpley. 1994. Solids transport and erodibility of poultry litter surface-applied to fescue. Trans. ASAE 37(3): 771-776.

Edwards, D. R., B. T. Larson, and T. T. Lim. 2000. Runoff nutrient and fecal coliform content from cattle manure application to fescue plots. J. American Water Resour. Assoc. 36(4): 711-721.

Ellis, J. R., and T. M. McCalla. 1976. Fate of pathogens in soils receiving animal wastes: A review. ASAE Paper No. 762560. St. Joseph, Mich.: ASAE.

Ferguson, C., A. M. de Roda Husman, N. Altavilla, D. Deere, and N. Ashbolt. 2003. Fate and transport of surface water pathogens in watersheds. Critical Reviews in Environ. Sci. and Tech. 33(3): 299-361.

Frenzel, S. A., and C. S. Couvillion. 2002. Fecal-indicator bacteria in streams along a gradient of residential development. $J$. American Water Resour. Assoc. 38(1): 265-273.

Gannon, J., U. Mingelgrin, M. Alexander, and R. J. Wagenet. 1991. Bacterial transport through homogenous soil. Soil Biol. Biochem. 23(12): 1155-1160.

Geldreich, E. E. 1978. Bacterial populations and indicator concepts in feces, sewage, stormwater, and solid wastes. In Indicators of Viruses in Water and Food, 51-97. Gerald Berg, ed. Ann Arbor, Mich.: Ann Arbor Science.

Gerba, C. P., C. Wallis, and J. L. Melnick. 1975. Fate of wastewater bacteria and viruses in soil. J. Irrig. and Drainage Eng. 101(3): 157-174.

Gilbert, R. G., C. P. Gerba, R. C. Rice, H. Bouwer, C. Wallis, and J. L. Melnick. 1976. Virus and bacteria removal from wastewater 
by land treatment. Applied and Environ. Microbiol. 32(3): 333-338.

GMU and Tetra Tech. 2004. Total Maximum Daily Load (TMDL) Development for Hawksbill Creek: E. coli (bacteria) impairment. Prepared by George Mason University and Tetra Tech, Inc., for Virginia Department of Environmental Quality, Richmond, Va. Available at: www.deq.virginia.gov/tmdl/apptmdls/shenrvr/hawksfc.pdf. Accessed 10 November 2005.

Guber, A. K., D. R. Shelton, and Y. A. Pachepsky. 2005. Transport and retention of manure-borne coliforms in undisturbed soil columns. Vadose Zone J. 4(3): 828-837.

Hagedorn, C., D. T. Hansen, and G. H. Simonson. 1978. Survival and movement of fecal indicator bacteria in soil under conditions of saturated flow. J. Environ. Qual. 7: 55-59.

Hartel P. G., W. I. Segars, J. D. Summer, J. V. Collins, A. T. Phillips, and E. Whittle. 2000. Survival of fecal coliform in fresh and stacked broiler litter. J. Applied Poultry Res. 9(4): 505-512.

Henry, L. A. 2004. Partitioning between the soil-adsorbed and planktonic phases of Escherichia coli. MS thesis. Blacksburg, Va.: Virginia Tech, Department of Biological Systems Engineering.

Horsley Witten. 1996. Identification and evaluation of nutrient and bacterial loadings to Maquoit Bay, New Brunswick and Freeport, Maine. Final report. Sandwich, Mass.: Horsley Witten, Inc.

Jackson, A., D. Roy, and G. Breitenbeck. 1994. Transport of a bacterial suspension through a soil matrix using water and an anionic surfactant. Water Research 28(4): 943-949.

Jamieson, R. C., R. J. Gordon, K. E. Sharples, G. W. Stratton, and A. Madani. 2002. Movement and persistence of fecal bacteria in agricultural soils and subsurface drainage water: A review. Canadian Biosyst. Eng. 44: 1.1-1.9.

Jamieson, R. C., R. J. Gordon, D. Joy, and H. Lee. 2004. Assessing microbial pollution of rural surface waters: A review of current watershed-scale modeling approaches. Agric. Water Mgmt. 70(1): 1-17.

Joy, J. 2004. Stillaguamish River watershed fecal coliform, dissolved oxygen, $\mathrm{pH}$, arsenic, and mercury Total Maximum Daily Load study. Olympia, Wash.: Washington State Department of Ecology, Environmental Assessment Program. Publication No. 04-03-017. Available at: www.ecy.wa.gov/pubs/0403017.pdf. Accessed 14 June 2006.

KDHE. 2006. Watershed planning section: Lower Kansas River $E$ coli bacteria TMDL. Topeka, Kansas: Kansas Department of Health and Environment. Available at: www.kdheks.gov/tmdl/index.htm. Accessed 1 February 2006.

Khaleel, R., K. R. Reddy, and M. R. Overcash. 1980. Transport of potential pollutants in runoff water from land areas receiving animal wastes: A review. Water Research 14(5): 421-436.

Koppelman, L. E., and E. Tanenbaum. 1982. The Long Island segment of the nationwide urban runoff program, D-18. Hauppauge, N.Y.: Long Island Regional Planning Board.

Larsen, R. E., J. R. Miner, J. C. Buckhouse, and J. A. Moore. 1994. Water-quality benefits of having cattle manure deposited away from streams. Bioresource Tech. 48(2): 113-118.

Lindqvist, R., and G. Bengtsson. 1991. Dispersal dynamics in groundwater bacteria. Microb. Ecol. 21: 49-71.

Ling, T. Y., E. C. Achberger, C. M. Drapcho, and R. L. Bengtson. 2002. Quantifying adsorption of an indicator bacteria in a soil-water system. Trans. ASAE 45(3): 669-674.

Maier, R. M., I. L. Pepper, and C. P. Gerba. 2000. Environmental Microbiology. San Diego, Cal.: Academic Press.

Mancini, J. L. 1978. Numerical estimates of fecal coliform mortality rates under various conditions. J. Water Poll. Control Fed. 51(1): 13-19.

Mankin, K. R., P. L. Barnes, J. P. Harner, P. K. Kalita, and J. D. Boyer. 2006a. Field evaluation of VFSs treating unstocked feedlot runoff. J. Soil and Water Cons. 61(4): (in press).

Mankin, K. R., L. Wang, S. L. Hutchinson, and G. L. Marchin. 2006b. Escherichia coli sorption to sand and silt loam soil. Trans. ASABE (in review).

MapTech. 2000. Fecal coliform TMDL (Total Maximum Daily Load) development for the south fork of the Blackwater River, Virginia. Prepared by MapTech, Inc., for the Virginia Department of Environmental Quality, Virginia Department of Conservation and Recreation, Richmond, Va. Available at: www.deq.virginia.gov/tmdl/apptmdls/roankrvr/sfblwtrpdf. Accessed 29 March 2005.

Marshall, K. C., R. Stout, and R. Mitchell. 1971. Selective sorption of bacteria from seawater. Canadian J. Microbiol. 17(11): 1413-1416.

McElroy, A. D., S. Y. Chiu, J. W. Nebgen, A. Aleti, and F. W. Bennett. 1976. Loading functions for assessment of water pollution from nonpoint sources. EPA 600/2-76-151. Washington, D.C.: USEPA Office of Water.

MDEQ. 2002. Fecal coliform TMDL for Abiaca Creek; Yazoo River Basin; Carroll, Holmes, and Leflore Counties, Mississippi. Jackson, Miss.: Mississippi Department of Environmental Quality, Office of Pollution Control, TMDL/WLA Section/Water Quality Assessment Branch. Available at: www.deq.state.ms.us/MDEQ.nsf/pdf/TWB_AbiacaCreekOc02/\$ File/YazooRiverBasinAbiacaCreekOct2002.pdf?OpenElement. Accessed 8 September 2005.

Menzel, R. G. 1980. Enrichment ratios for water quality modeling. In CREAMS: A Field-Scale Model for Chemicals, Runoff, and Erosion from Agricultural Management Systems, 486-492. Conservation Research Report 26. W. G. Knisel, ed. Washington, D.C.: USDA

Moore, J. A., M. E. Grismer, S. R. Crane, and J. R. Miner. 1982. Evaluating dairy waste management systems' influence on coliform concentration in runoff. In Station Bulletin 658. Corvallis, Ore.: Oregon State University, Agricultural Experiment Station.

Moyer, D. L., and K. E. Hyer. 2003. Use of the Hydrological Simulation Program-FORTRAN and bacteria source tracking for development of the fecal coliform Total Maximum Daily Load (TMDL) for Christians Creek, Augusta County, Virginia. USGS Water-Resources Investigations Report 03-4162. Washington, D.C.: U.S. Geological Survey. Available at: www.deq.virginia.gov/tmdl/apptmdls/shenrvr/chrstnfc.pdf. Accessed 31 March 2005.

Mubiru, D. N., M. S. Coyne, and J. H. Grove. 2000. Mortality of Escherichia coli O157:H7 in two soils with different physical and chemical properties. J. Environ. Qual. 29: 1821-1825.

Muñoz-Carpena, R., and G. Vellidis, A. Shirmohammadi and W.W. Wallender. 2006. Modeling tools for TMDL development and implementation. Trans. ASABE 49(4): 961-965.

Murphy, E. M., and T. R. Ginn. 2000. Modeling microbial processes in porous media. J. Hydrogeology 8(1): 142-158.

NCSU. 1994. Livestock manure production and characterization in North Carolina. Raleigh, N.C.: North Carolina Cooperative Extension Service and North Carolina State University, College of Agriculture and Life Sciences.

Neilson, B. T., J. S. Hornsburgh, D. K. Stevens, M. R. Matassa, and J. N. Brogdon. 2003. EPRI's Watershed Analysis Risk Management Framework (WARMF) vs. USEPA's Better Assessment Science Integrating Point and Nonpoint Sources (BASINS). In Proc. Total Maximum Daily Load (TMDL) Environ. Regulations II, 460-470. ASAE Publication 701P1503. St. Joseph, Mich.: ASAE.

Paul, S., P. K. Haan, M. D. Matlock, S. Mukhtar, and S. D. Pillai. 2004. Analysis of the HSPF water quality parameter uncertainty in predicting peak in-stream fecal coliform concentrations. Trans. ASAE 47(1): 69-78.

Parajuli, P., K. R. Mankin, and P. L. Barnes. 2005. Calibration and validation of SWAT/Microbial submodel for fecal coliform bacteria prediction on a grazed watershed. ASAE Paper No. 052126. St. Joseph, Mich.: ASAE. 
Payment, P., A. Berte, M. Prevost, B. Menard, and B. Barbeau. 2000. Occurrence of pathogenic microorganisms in the Saint Lawrence River (Canada) and comparison of health risks for populations using it as their source of drinking water. Canadian J. Microbiol. 46: 65-576.

Pope, M. J., and T. E. Cherry. 2000. An evaluation of the presence of pathogens on broilers raised on poultry litter treatment ${ }^{\circledR}$-treated litter. Poultry Sci. 79(9): 1351-1355.

Pradhan, S., M. T. Hoover, H. A. Devine, J. G. Arnold, and M. DiLuzio. 2005. Quantifying nitrogen exports from on-site systems to surface waters within small watersheds using the SWAT model. In Proc. Watershed Management to Meet Water Quality Standards and Emerging TMDL, 387-396. ASAE Publication 701P0105. St. Joseph, Mich.: ASAE.

Reddy, K. R., R. Khaleel, and M. R. Overcash. 1981. Behavior and transport of microbial pathogens and indicator organisms in soils treated with organic wastes. J. Environ. Qual. 10(3): 255-266.

Rosen, B. H. 2000. Waterborne pathogens in agricultural watersheds. Burlington, Vt.: USDA-NRCS Watershed Institute, University of Vermont.

Sadeghi, A. M., and J. G. Arnold. 2002. A SWAT/microbial submodel for predicting pathogen loadings in surface and groundwater at watershed and basin scales. In Total Maximum Daily Load (TMDL) Environmental Regulations, 56-63. ASAE Publication 701P0102. St. Joseph, Mich.: ASAE.

Schepers, J. S., and J. W. Doran. 1980. Effect of grazing management on the chemical and microbiological aspects of the environment. In Proc. Nebraska Forage and Grassland Council, 37-41. Lincoln, Neb.: Nebraska Forage and Grassland Council.

Sharma, M. M., Y. I. Chang, and T. F. Yen. 1985. Reversible and irreversible surface charge modification of bacteria of facilitating transport through porous media. Colloids Surf. 16(2): 193-206.

Shelton, D. R., Y. A. Pachepsky, A. M. Sadeghi, W. L. Stout, J. S. Karns, and W. J. Gburek. 2003. Release rates of manure-borne coliform bacteria from data leaching through stony soil. Vadose Zone J. 2(1): 34-39.

Shirmohammadi, A., I. Chaubey, R. D. Harmel, D. D. Bosch, R. Muñoz-Carpena, C. Dharmasri, A. Sexton, M. Arabi, M. L. Wolfe, J. Frankenberger, C. Graff, and T. M. Sohrabi. 2006. Uncertainty in TMDL models. Trans. ASABE 49(4): 1033-1049.

Soupir, M. L., S. Mostaghimi, E. R. Yagow, C. Hagedorn, and D. H. Vaughan. 2006. Transport of fecal bacteria from poultry litter and cattle manures applied to pastureland. Water, Air, and Soil Poll. 169(1-4): 125-136.

Springer, E. P., G. F. Gifford, M. P. Windham, R. Thelin, and M. Kress. 1983. Fecal coliform release studies and development of a preliminary nonpoint-source transport model for indicator bacteria. Logan, Utah: Utah State University, Utah Water Research Laboratory.

Stiles, T. C. 2001. A simple method to define bacteria TMDLs in Kansas. In Proc. TMDL Science Issues Conference, 375-378. Alexandria, Va.: Water Environment Federation, and Washington, D.C.: Association of State and Interstate Water Pollution Control Administrators.

Stiles, T. C. 2002. Incorporating hydrology in determining TMDL endpoints and allocations. In Proc. National TMDL Science and Policy 2002 Specialty Conference, CD-ROM. Alexandria, Va.: Water Environment Federation.

Tay, Y., J. T. Gannon, P. Baveye, and M. Alexander. 1994. Transport of bacteria in an aquifer sand: Experiments and model simulations. Water Resources Research 30(12): 3243-3252.

Thelin, R., and G. F. Gifford. 1983. Fecal coliform release pattern from fecal material of cattle. J. Environ. Qual. 12: 57-63.

Tian, Y. Q. P. Gong, J. D. Radke, and J. Scarborough. 2002. Spatial and temporal modeling of microbial contaminants on grazing farmlands. J. Environ. Qual. 31(3): 860-869.

Tyrrel, S. F., and J. N. Quinton. 2003. Overland flow transport of pathogens from agricultural land receiving faecal wastes. J. Applied Microbiol. 94(S1): 87-93.
Unc, A., and M. L. Goss. 2006. Culturable Eshceria coli in soil mixed with two types of manure. SSSA J. 70: 763-769.

USEPA. 1986. Ambient water quality criteria for bacteria. EPA440/5-84-002. Washington, D.C.: USEPA Office of Water Regulations and Standards.

USEPA. 1998. Bacterial water quality standards for recreational waters (freshwater and marine waters). Status report. EPA-823-R-98-003. Washington, D.C.: USEPA Office of Water.

USEPA. 2000. Bacterial Indicator Tool: User's Guide. EPA-823-B-01-003. Washington, D.C.: USEPA Office of Water. Available at: www.epa.gov/waterscience/BASINS/ bs3tbit.htm. Accessed 16 December 2005.

USEPA. 2001. Protocol for developing pathogen TMDLs. 1st ed. EPA 841-R-00-002. Washington, D.C.: USEPA Office of Water.

USEPA. 2002. Implementation guidance for ambient water quality criteria for bacteria. EPA-823-B-02-003. Washington, D.C.: USEPA Office of Water.

USEPA. 2003. Total Maximum Daily Loads for bacteria in the Malibu Creek watershed. San Francisco, Cal.: USEPA Region 9. Available at: www.epa.gov/region09/water/tmdl/malibu/final_bacteria.pdf. Accessed 8 September 2005.

USEPA. 2004. Metals, $\mathrm{pH}$, and fecal coliform TMDLs for the Guyandotte River watershed, West Virginia. Philadelphia, Pa.: USEPA Region 3. Available at: www.epa.gov/reg3wapd/tmdl/wv_tmdl/Guyandotte/index.htm. Accessed 8 September 2005.

USEPA. 2005a. Total maximum daily loads: National section 303(d) list fact sheet: Top 100 impairments. Washington, D.C.: USEPA Office of Water. Available at: www.oaspub.epa.gov/waters/national_rept.control\#TOP_IMP. Accessed 26 April 2005.

USEPA. 2005b. Water quality standards: Basic information. Washington, D.C.: USEPA Office of Water. Available at: www.epa.gov/OST/standards/about/. Last updated 8 February 2005. Accessed 14 December 2005.

USGS. 2006. Earth Resources Observation and Science (EROS). Washington, D.C.: U.S. Geological Survey. Available at: http://edc.usgs.gov/. Last updated 2 February 2005. Accessed 19 July 2006.

Vadas, P. A., P. J. A. Kleinman, and A. N. Sharpley. 2004. A simple method to predict dissolved phosphorus in runoff from surface-applied manures. J. Environ. Qual. 33(2): 749-756.

VDEQ. 2003. HSPF model calibration and verification for bacteria TMDLs. Guidance Memo 03-2012. Richmond, Va.: Virginia Department of Environmental Quality. Available at: www.deq.state.va.us/water. Accessed 16 December 2005.

Wang, L. 2003. Fecal bacteria survival in cow manure and Escherichia coli release and transport through porous media. $\mathrm{PhD}$ diss. Manhattan, Kansas: Kansas State University, Department of Biological and Agricultural Engineering.

Wang, L., K. R. Mankin, and G. L. Marchin. 2004. Survival of fecal bacteria in dairy cow manure. Trans. ASAE 47(4): 1239-1246.

Williams, J. R., and R. W. Hann. 1978. Optimal operation of large agricultural watersheds with water quality constraints. Tech. Report 96. College Station, Texas: Texas A\&M University, Texas Water Resources Institute.

Yagow, G. 2001. Fecal coliform TMDL Mountain Run watershed, Culpeper County, Virginia. Blacksburg, Va.: Virginia Tech, Department of Biological Systems Engineering. Available at: www.deq.virginia.gov/tmdl/. Accessed 1 November 2004.

Young, K. D., and E. L. Thackston. 1999. Housing density and bacterial loading in urban streams. J. Environ. Eng. 125(12): 1177-1180.

Zeckoski, R. W., B. L. Benham, S. B. Shah, M. L. Wolfe, K. M. Brannan, M. Al-Smadi, T. A. Dillaha, S. Mostaghimi, and C. D. Heatwole. 2005. BSLC: A tool for bacteria source characterization for watershed management. Applied Eng. in Agric. 21(5): 879-889. 